\title{
THE LEgal FramewORK FOR ACQUIRING WATER ENTITLEMENTS FROM EXISTING USERS
}

\author{
NIGEL BANKES ${ }^{*}$
}

This article provides a detailed analysis of the legal framework under Alberle's Water Act and Irrigation Districts Act, pursuant so which a person may acquire an entitlement to water from an existing user. The first part of the article covers both the agreement to assign water as well as the licence transfer procedure introduced in the new Water Act. The second part of the article deals with the creation of derivative rights to water by irrigation districts, including rural water use agreements and water conveyance agreements. The article also examines the temporary and permanent assignments of rights to irrigable acreage within irrigation districts.
Cet arricle anolyse en détail le cadre législatif de lo Water Act ef de l'Irrigation Districts Act de l'Alberia, les lois sur le regime des eanx et des districks d'irrigation, aux rermes desquelles une persome peut acquerir d'un wilisatem pré-cxistant le droit aux ressontres hydrauliques. La première partie de larticle traite de l'entente touchom la cession de l'eall. ainsi que des procédures de transfert de la licence contenues dans la nouvelle loi : Water Act. La deuxième partie de l'article traite de la création par les districts d'irrigation de droits dérives anx ressources hydrauliques, $y$ compris les ententes d'unilisation des ressources hydrauliques rurales et les ententes d'adduction d'cau. L'article examine également les actes de cession temporaire et permonente des droits aur superficies irrigables à l'intérieur des districts d'irrigation.

\section{TABLE OF CONTENTS}

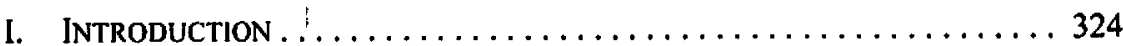

II. SOME THEMES From THE LiteratURE ON WATER

TRANSFERS AND THE MARKETING OF WATER $\ldots \ldots \ldots \ldots \ldots \ldots \ldots, 328$

A. FORMAL AND INFORMAL TRANSFER REgimes

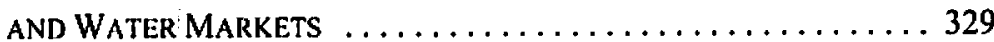

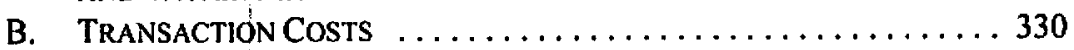

C. THE BENEFITS OF WATER TRANSFER AND

MARKeting Regimes ........................ 331

D. THE "COSTS" OF WATER TRANSFER REgIMES .......... 331

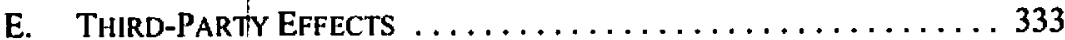

F. THE ROLE of WATER USE ASSOCIATIONS $\ldots \ldots \ldots \ldots \ldots \ldots . \ldots \ldots 33$

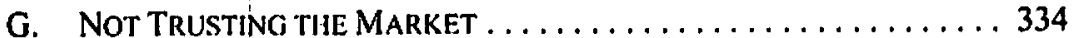

III. Rights Avallabi.E UNDER the WateR $A C T \ldots \ldots \ldots \ldots \ldots \ldots \ldots, \ldots \ldots$

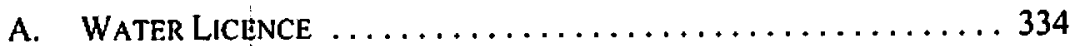

B. REgistered Traditional AgRICULTURAL USER $\ldots \ldots \ldots \ldots 336$

C. THE TRANSFERABILITY OF ENTITLEMENTS

UNDER THE $W_{A T E R} A C T \ldots \ldots \ldots \ldots \ldots \ldots \ldots \ldots \ldots \ldots \ldots \ldots$

Professor of Law, University of Calgary. E-mail: ndbankes@ucalgary.ca. The idea for this article emerged as a result of discussions with an informal water law research group of the Faculty of Law at the University of Calgary, which suggested that we needed a more systematic account of the different ways in which it might be possible to effect "transfers" of water and water rights in Alberta. Members of the group who participated in this discussion included colleagues Arlene Kwasniak, Mike Wenig, and Ted Horbulyk (Department of Economics). The author's work in water law was supported by the Alberta Ingenuity Fund and that support is gratefully acknowledged. Christina Smith and Michelle Forretier provided research assistance. I also thank the two Alberta Law Review referees for their comments. 


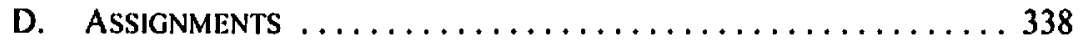

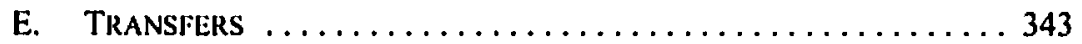

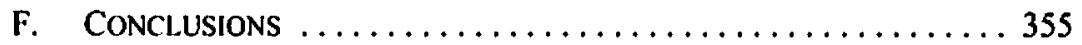

G. AN EXCURSUS: SPECIAL FormS OF:

“TrANSFERs" . ............................. 356

IV. RIGHTS AVAILABLE. UNIER TIII:

IRRIGATION DISTRICTS ACT . . . . . . . . . . . . . . . . . . . . 357

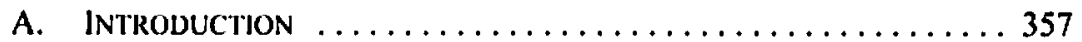

B. What Do the VARIOUS ENTITIEMENTS AUTHORIZE? . . . . . . 359

C. What Priority Is AcCorded to Eacil

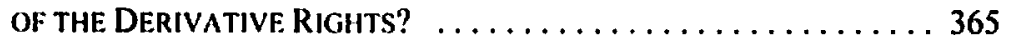

D. What IS THE DURaTION OF Each OF THE

Derivative Rights ....................... 366

E. IDS AND TEMPORARY AGREEMENTS TO ASSIGN

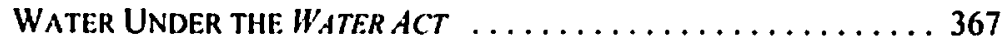

F. THE TRANSFERABILITY OF ENTITLEMENTS UNDER

THE IRRIGATION DISTRICTS ACT . . . . . . . . . . . . . . . 368

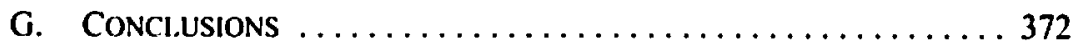

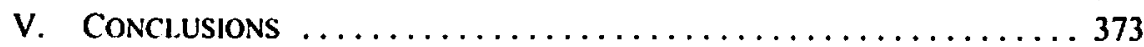

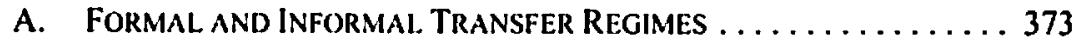

B. TRANSACtion Costs ...................... 373

C. Benffits, Costs, THird Party EFfects, AND the

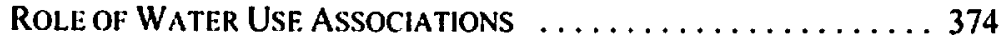

D. (NOT) TRUSTING TIIE MARKET ..................... 375

\section{INTRODUCTION}

This article describes and analyzes the legal framework that controls the circumstances under which a person can obtain a water entitlement from an existing water user. The principal statutes that are the subject of this analysis are the Water Act' and the Irrigation Districts Act. ${ }^{2}$ The premise for the article is that while a new user may be able to acquire an original water right from the Crown in the form of a new licence, this will not always be the case. Furthermore, there are reasons for thinking that a ncw licence, even where available, may not provide adequate security of supply for some users. As to the first, a new user will not be able to secure a new right if the Director has made an order under the Water Acr that no new licence applications will be accepted for that particular water body. ${ }^{3}$ For example, Phase One of the South Saskatchewan River Basin Water Management Plan ${ }^{4}$ recommended

R.S.A. 2000, c. W-3.

R.S.A. 2000 , c. I-1 I [ $[D A]$. I acknowvledge that even this is only a partial picture. A more complete analysis would need to deal with opportunities to acyuire rights to water from other important licensees including municipalities and other water providers and utilitics.

Supra note I. s. 53. The Director may make such an order wilh respect to a water managennent areu "or other geographical area" lor a specilied period of time. "The Director may exlend that period of time following a public review. The section preseribes the factors that the Director must and may consider in making a decision to close a basin to further applications.

Alberta Environment, South Saxkatchewan River Basin Water Management Plan. Phase One. Water Allocation Transfers (June 2002) at 12, online: Alberta Environment <www3.gov.ab.ca/env/water/ regions/ssrb/phase_onc.asp> [SSR13 WMP]. The Draft Phase Two Plan, released 18 October 2005 , 
that the Director close the southern tributaries of the Oldman River (St. Mary, Belly, and Waterton) to further applications "as an interim measure" pending completion of Phase Two of the planning process. 'The Director adopted this recommendation. Consequently, in this situation, our potential user has no choice but to acquire an entitlement from an existing rights holder. Conditions of scarcity are not confined to the southern part of the province. Mining and in situ oil sands operations in northern Alberta require large volumes of water, most of which are taken trom the Athabasca River. Stakeholders acknowledge that the river cannot support the needs of all planned mining operations, especially during low flow winter months."

As to the second premise of this article, since Alberta's Water Act is based upon a licensed prior appropriation or a first-in-time, first-in-right priority system, a new, and therefore junior, right may be cut off in a dry year. ${ }^{7}$ While this may be acceptable for some potential users, it may pose an unacceptable level of risk to another user. ${ }^{8}$ Such a user will either want to be able to secure all of its water from an existing user with a senior priority or, at the very least, will want to know that it will be able to acquire a supplementary source of water from a third party in those dry years."

continues this recommendation (at 7) and extended it to include not just the three southern tributaries, but also the Bow, South Saskatchewan, and the entire Oldman Basin. It also proposed setting an allocation limit for the Red Deer River sub-basin. The Approved Water Management Plan for the South Saskatchewan (Alberta) was made available August 2006 and is available online: Alberta Environment <www.3.gov.ab.ca/env/water/regions/ssrb/plan.html> [SSRB Approved Plan]. The SSRB Approved Plan (at 6) affirms the draft recommendation. The reader is cautioned that it has not been possible to revise the article to reflect all of the changes made to the Dralt Plan by the SSRB Approved Plan.

There are other examples of basin closures or moratoria. Because ol eoncerns about its apportionment obligations under Article VI of the Boundary Waters Trealy, 1909. Alberta placed a moratorium on new water rights in the Milk River basin in September 1985 (Southern Tributaries Ad Iloc Task Force, Southern Tributaries of the Lfilk River: Evaluation of Water Manugement Opportunities. Final Report (November 1993) at 19). That moratorium is still in effect. John Thompson (Watrecon Consulting). Environment for Grow $/$ : People to Water, Hater to People, Alberta Institule of Agrologists (AIA) Discussion Paper (March 2005) at 4, notes that the government placed a moratorium on new rights in the Highwood in 1977. lifted it in 1981, and reinstated it in 1983. While the Act seems only to contemplate closures for a particular period of time rather than perpetual closures there is some reason for thinking that a basin. once closed. should ordinarily remain closed barring a new development such as the addition of major storage. A closure serves to cap the size of the resource and thereby facilitate the development of a market. The possibility that the waterbody will be re-opened may ereale uncertainty and weaken the emerging market. In support of this approach see Thompson, ibid. at 13. National Energy Board (NEB), Canoda's Oil Sands: Oppornmities and Challenges ro 2015: An Cipdale (June 2006), online: NEB <www,neb-one.gc.ca/energy/EnergyReports/HOilSands>at 38.

Supra note I, s. 30, and for further discussion see David R. Percy. "Seventy-Five Years ol'Alberta Water Law: Maturity; Demise \& Rebirth" (1996) 35 Alta. L. Rev. 22I. In David R. Percy, The Frame'work of Water Rights Legislation in Canada (Calgary, Alta.: Canadian Institute of Resources Law, 1988) at 1315 [Percy, Framework of Water Rights]. the author makes it plain that he prefers the term "prior allocation" to the term "prior appropriation" on the basis that the former more accurately captures the point that in western Canada rights arise by virtue of the governnental licensing system rather than the actual appropriation of water. I agres with the point but hope to capture the same idea by using the phrase "licensed prior appropriation" system.

* For example, a grower of specialty vegelables may run the risk of losing an entire crup if denied access to irrigation water at critical times, or a food processing plant may need to be assured of a continuous supply of water to satisfy licensing requirements or simply in order to be prolitable.

4 There may be other potential transferees such as a secured creditor of the transleror. The secured creditor will want answers to such questions as: (1) can I take a water licence as security or is it only available as security in association with the parcel of land to which it is appurtenant; or (2) ifl realize on a water licence as security. how marketable is that asset? What restrictions stand in the way of my being able to realize the value of that asset? 
In sum, conditions of scarcity require us to consider the transferability of existing entitlements. Those same conditions of scarcity also suggest that there are welfare and efficiency gains to be realized from facilitating transfers as water moves from low value uses to higher value uses.

One of the key innovations of Alberta's new Water Act, which came into force in 1999, is a set of provisions (ss. 81-83) permitting and regulating the transfer of water licences. Under the old Water Resou'ces $A c t^{\prime 0}$ licences were issued for a particular purpose, were appurtenant to particular land, and passed with the land when the land was conveyed. They were generally not otherwise transferable. " The drafters of the new Act lavished considerable attention on the approval process required for transfers. The scheme that the $A c t$ puts in place endeavours to ensure that proposed transfers do not have a detrimental impact on other users or on the aquatic environment.

These transfer provisions have attracted considerable attention and were much touted at the time the $A C l$ was passed. It is less well understood that these sections of the $A C l$ do not provide the only means by which water entitlements in Alberta may be transferred or acquired. Not only does the Water $A c t$ itself provide for "agreements to assign water" but, and much more significantly, the $I D A$ provides several forms of agreement ${ }^{12}$ by which a person can acquire rights (hereafter referred to as derivative rights) from an irrigation district (ID) or from an individual holder of rights to irrigable acres within the ID.

This suggests that in the case of an ID we need to think about the transferability of an entillement to water from at least three different levels. At the first level, an ID is much like any other licensec. Thus, an ID may acquire rights from another person but may also assign or transfer all or a portion of its rights under the terms of the Water $A c t .{ }^{13}$ At the second level,

R.S.A. 1980, c. W-5; see in particular s. 11 (listing purposes) and s. 23 (appurtenancy).

" David R. Percy. "Water Rights in Alberna" (1977) I5 Alta. L. Rev. 142 at 148-49 and Ruth E. Frecman \& Terrence S. Veeman, "Economic Aspects of Transferable Water Rights in Alberta" in D. Manz, ed., Water and the Wilderness: Development. Stewardship. Management (Banff, Alta.: Canadian Water Resources Association. 1993) 261. The former Act (ibid., s. II(4)) did provide one extraordinary mechanism for reallocating water based upon a system of statutory priorities. Under that scheme (discussed in Percy. Framework of Water Rights, supra note 7 at 24-25), a user higher in the priority scheme (e.g., a municipality) might apply to the Minister to have a lower priority licence cancelled (e.g., a licence held by an irrigator) and a new licence issued to the applicant with the same priority as the cancelled licence. The former licensee was entilled to compensation. Percy comments that this was essentially an "expropriation" and that "this method of transfer has been cmployed only rarely ... [and] functions as little more than a safety-valve" (at 25).

12 The forms of agreement include not only the basic entitlement to irrigable acreage but also other forms of irrigation agreements, as well as household purposes agreements and rural water use agreements. There is one difference, however, insofar as $s$. II of the $I D A$ imposes additional procedural constraints on an ID wishing to assign all or part of its licence. Sec discussion infra, in Part III.E.2 of the article. Furthermore, there is authority to the effect that the terms of the irrigation legislation will affect how the courts will interpret the requirements of the general water legislation as applied to IDs. See Friends of the Oldman River Society v. Alherta (Minister of Environmensal Protection) (1996), 38 Alta. L.K. (3d) 76 (C.A.) [Friends of the Oldman River]. In that case, the Court rejected an argument that the Minister could only issue a lieenee to an ID if the application for the licence specified in advance the precise lands to be irrigated. The Court held that such a literal interpretation of the Water Resenurces $A C l$ and regulations, while perhaps applicable to an ordinary applicant, would undermine the authority accorded to IDs by the irrigation legislation. hence "when an Irrigation District applies for a licence under the $A C t$ it is sufficient to specily that the land to he irrigated will be in the Irrigation District, without identifying 
a person may acquire a right to water from an ID by entering into a form of derivative rights agreement with the ID under the terms of the IDA. This agreement may take the form of a right to water to irrigate a certain acreage or it may take the form of a domestic use or rural water use agreement allowing the user to use the water for a variety of other, non-irrigation, purposes. These agreements may provide a set of rights that are functionally very similar to those that a person may acquire by means of a transfer or assignment under the Water Act. At the third level, at least one of the derivative rights that a person may acquire from an ID is itself alienable. Thus, as we shall see, the holder of the right to irrigable acres may transfer the rights associated with irrigable acres to another irrigator or enter into an alternate parcel irrigation agreement.

The analysis of the role of ID water rights is especially significant given the dominant position of licences held by jrrigation districts in the South Saskatchewan River Basin. Not only are these rights often among the most senior rights in any particular water body, but they account for over 70 percent of licensed volumes in the Basin. ${ }^{14}$

In sum, a person interested in acquiring a right to water in a closed basin or interested in acquiring a more senior right may be able to do so either by entering into an assignment or transfer under the Water Act or, if within or adjacent $10^{15}$ the service area of an ID, may be able to acquire a right to water through an agreement with the ID or with the holder of rights to irrigable acres.

It is therefore important to understand the characteristics of these different arrangements if we are to understand how a market in water rights may emerge in Alberta. Private partics seeking to acquire rights will need to understand the advantages and disadvantages of the various options and the transaction costs associated with them. ${ }^{16}$ From a public interest perspective we need to understand which forms of transfer will engage a regulatory review

the particular pareel or the name and address of its owner" (at para. 16). This case relates to the now repealed versions of the provincial water and irrigation statutes but the basic approach and conclusion may still be persuasive.

Alberta Environment, South Suskatchenan River Basin. Nater Allocalion, May 2003 (Revised January 2005) at 30-33 [Alberta Environment]. Pic diagrams in this publication show that fully 74.58 percent of licences by volume in the basin are licensed to irrigation users. While there are some privale irrigators most of this water is licensed to IDs. The situation is even starker when one considers some of the subbasins: e.g. the Oldman River where irrigation accounts for 87.42 percent of licensed use in the basin. In at least some cases, ID licences expressly authorice service outside the formal area of the ID: see the references in Western Irrigation District v: Trobst (1990), 103 A.R. 65 (Q.B.) at para. 6. afTd (1991), I 15 A.R. 64 (C.A.) [Trobst] to the Western Irrigation District's final licence of 1963 (with a priority date of 1915) authorizing diversion of water from the Bow River for irrigation of lands described in the licence "and to supply water for domestic purposes within and without the District" [emphasis added]. Markets work most effeclively when property rights are fully defined: Theodore $M$. Horbulyk. "Markets, Policy and the Allocation of Water Resources Among Sectors: Constraints and Opportunities" (2005) 30:1 Canadian Water Resources Journal 55 esp. at 59.60; Freman \& Vecman. supra note II at 267 (“Fundamental to any system of transferable waler rights are clearly delined rights and uses"). Markets also work best when dealing with homogenous products but appropriative rights are far from homogenous: George A. Gould, "Waler Rights Transfers and Third-Party Fifects" (1988) 23 Land \& Water L. Rev. 1 at 22 ("each right is unique," "the priority date and the point of diversion, place of use, and purpose of use" set the parameters differently for each appropriative right). The two points are related, an efficient market requires that we can clearly describe not only the licensed appropriation but also that part of it that can be Iransferred. potentially a "consumptive entitlement" (ibid. at 25). 
and an assessment of the impact of the proposed transfer, and which are more "private" in nature and will not attract the same degree of public scrutiny. ${ }^{17}$

Finally, it bears emphasizing that while transfers and assignments under the Water Act and the various forms of derivative rights agreements under the $I D A$ represent particularly important ways in which a new user may acquire a right to water, they are not exhaustive of the range of possibilities. For example, a new user such as a golf course operation might seck to acquire a water supply from a municipality (which is perhaps not fully using its existing licensed entitlement) rather than directly from the Crown or from an ID. However, in the interest of keeping this article within a manageable size, I do not further discuss the legal issues associaled with acquiring a water supply from a municipality.

The balance of the article proceeds as follows. Part II seeks to provide a broader context for discussing developments in Alberta by providing a brief survey of some of the main themes that emerge in the law and economics literature on water transfers and the marketing of water. Part III focuses on entillements to water under the Water Act. For each form of entitlement, the article seeks to analyze the rights conferred by the entitlement and the duration and priority of the right. The article then analyzes the two main forms of "transfer" available under the Water $A c t$, the $\mathrm{s} .33$ agreements to assign and s. 81 transfers. ${ }^{18} \mathrm{~A}$ brief excursus discusses the inter-basin transfer provisions of the Water Act. Part IV of the article provides the same description and analysis of the position under the IDA. The conclusions provide an assessment of Alberta's legislative framework in light of the themes that emerged from the literature discussed in Part II.

\section{Some Themes From the Literature on Water Transfers AND THE MARKETING OF WATER}

There is an extensive body of literature on water transfers and the marketing of water and water rights. While much of this literature is authored by economists ${ }^{19}$ there are also significant contributions from legal academics, especially in the United States. ${ }^{20} \mathrm{~A}$ complete

17 For example, one might hypothesize that a combination of: (1) high transaction costs; (2) the fear of departmental scrutiny of licence validity; and (3) the risk of imposition of the conservation holdback will all lead parties to seck to acquire a derivative right from an ID rather than through the mechanism of a transfer under $\mathrm{s} .81$ of the Water $A c t$.

A. Dan Tarlock. "Water Transfers: A Means to Achieve Sustainable Water Use" in Edith Brown Weiss, Laurence Boisson de Chazournes \& Nathalie Bernasconi-Osterwalder, eds., Fresh Water and International Economic Law (Ox ford: Oxford University Press, 2005) 35 at 37 [Fresh Water] noles that the term "water transfer" is a generic term but one that traditionally referred to changes in the use or point of use of an existing entitlement. See also Gould, supra note 16 at 13, suggesting "a 'transfer" indicates a change in purpose of use and/or a change in place of use, which often incidentally requires a change in point of diversion."

Particularly useful collections include: K. William Easter, Mark W. Rosegrant \& Ariel Dinar, eds., Markets for Water: Potemial and Perfornance (Boston: Kluwer Academic Publishers. 1998) (Markets: for Water] and K. William Easter \& Mary E. Renwick, eds., Economics of Water Resources: Instifurions, Instrumems and Policies for Managing Scarcity (Burlington, Vt.: Ashgate Publishing. 20(24)|Economics of Water Resources].

:D Tarlock, supra note 18; Joseph L. Sax. "Understanding Transfers: Community Rights and the Privatization of Water" (1994) 1 West-Northwest Journal of Environmental Law and Policy 13; and Gould, supra nole 16. Lawrence J. MacDonnell, "Transferring Water Uses in the West" (1990) 43 Okla. L. Rev. 119. offers useful historical context noting that when appropriative rights were first developed 
assessment is beyond the scope of this article but discussion of some of the main themes will help provide a context for assessing Alberta's legislation. These themes are as follows: (1) formal and informal transfer regimes; (2) transaction costs; (3) the benefits of water transfer and marketing regimes; (4) the costs of water transfer regimes; (5) third party effects; (6) the role of water use associations; and (7) not trusting the market.

Discussions of water marketing begin with the recognition that water is a scarce resource..$^{21}$ This recognition may result from closing water basins to further allocations as discussed above, but it may also result from the appreciation that major new supplies of water cannot be secured because the economic, environmental, or social costs of building new storage or engaging in major water basin transfers cannot be justified. The uncertainties associated with climate change (which may result in less precipitation, seasonal changes in the timing of precipitation, and changes in the form of precipitation - more rain, less snow) contribute to an appreciation of scarcity. Scarce resources need to be allocated.

Various instrument choices exist for effecting the allocation of scarce resources. One method is a command and control allocation based upon a prescribed principle. Possible principles include prior appropriation, prorationing based upon historical use, a principle of proportionality or correlative user (e.g., a riparian-type system), or some form of equitable apportionment (common in an interjurisdictional context). Another approach that was reflected in the former water legislation of the Province is to create a statutory priority for certain uses over others (e.g., the priority list under the former $A c t$ went from domestic, municipal, irrigation, industrial, etc.). Yet another method is to use the market to effect an allocation or a reallocation of the resource.

\section{A. Formal ANd INFormal. TRANGFer REgimes ANd WATER MARketS}

Some of the economics literature distinguishes between formal and informal water markets. 22 Formal markets are characterized by a clear definition of the rights subject to trade; sales may be for a specified volume, or share of water for a fixed period or permanently. Trades are enforceable by the legal system in the same manner as conventional property and contract transactions. Informal markets usually involve the sale of unmeasured flows of water for a particular time from a pump or canal. Trades are enforced not by the dominant legal system but by reputation of individuals and trust within the irrigation

in the context of the mining industry there was a broad understanding that rights should be transferrable. Restrictions on the transferability of water were enacted as irrigation became a more dominant use. The statutory prohibitions on non-appurtenant transfers started to be abolished in Arizona in 1962, followed by Wyoming in 1973, Calilomia in 1980. Utah in 1988, and Colorado in 1989.

2 Where water is not scarec one would not expect to see markets emerge and govemments should not invest in creating the necessary institutions (public goods) to facilitate market transactions absent conditions of scarcity.

$\because \quad$ The discussion in this paragraph is based on K. William Fasier, Mark W. Rosegrant \& Aricl Dinar, "Formal and Informal Markets for Water: Institutions, Performance and Constraints" in Economics of Water Resources, jupra nole 19, 393 and K. William Laster, Mark W. Rosegrant \& Aricl Dinar, "The Performance of Water Markets: Transaction Costs, Interjurisdictional Barriers and Institutional Options" in Richard Just \& Sinaia Netanyahu, eds., Conflict and Ceoperation on Trans-Boundany Water Resources (Uoston: Kluwer Academic Publishers, 1998) 299 [Easter, Rosegrant \& Dinar. "Performance of Water Markets']). 
community. Easter $e t$ al. suggest that formal markets predominate in North and South America, while informal markets are concentrated in the irrigated areas of south Asia. ${ }^{23}$

Formal markets may be most suited to jurisdictions where there is a long-standing commitment to market institutions and the rule of law, and where governments have the resources and capacity to establish the appropriate institutional and organizational arrangements to facilitate operation of the formal market. ${ }^{24}$ Formal markets may be most needed to deal with trades that go beyond the local community, trades that are not just temporary, and trades that occur between (rather than simply within) sectors with more farreaching third-party effects. Informal markets may be most likely to develop within geographically confined areas and amongst community members and, perhaps, between members of water use associations.

By their nature formal markets lend themselves to government supervision (e.g., prior approval of trades) while informal markets do not. Consequently, it is easier to protect third party interests in the context of formal rather than informal markets.

Lorraine Nicol has applied this typology to markets for irrigation rights in Alberta. ${ }^{25}$ For Nicol, the formal market refers to transfers of long-term entitlements, while the informal market involves the temporary transfer of rights to certain volumes of water. In Nicol's analysis the former is represented in Alberta by the formal transfer procedure of $s .81$ of the Water $\mathrm{ACl}$, while the latter is represented by the opportunities available to individual irrigators within an ID to trade their irrigation rights within the ID. ${ }^{26}$

\section{B. Transaction Costs}

While conventional neoclassical economics may work with an assumption of perfect competition in which resources are costlessly mobile and individuals have perfect information about market opportunities, ${ }^{27}$ the reality is that water traders may incur significant transaction costs in effecting trades, especially when a market is in its nascent stages and lacks the private (e.g., brokers) and public (e.g., stock markets and futures markets) institutions necessary to facilitate trades. High transaction costs will tend to raise the market price of water and therefore reduce the amount of water traded. ${ }^{28}$ Easter et al. identify two types of transaction costs, administratively-induced transaction costs and policyinduced transaction costs. ${ }^{29} \mathrm{Administratively-induced} \mathrm{transaction} \mathrm{costs} \mathrm{refer} \mathrm{to} \mathrm{such} \mathrm{things}$ as the costs of searching for and matching buyers and sellers, and the subsequent negotiations

Easter, Rosegrant \& Dinar, "Performance of Water Markets," ibid.

K. William Easter, Mark W. Rosegrant \& Aricl Dinar, "The Future of Water Markets: A Realistic Perspective" in Markets for Water, supra note 19, 277.

Lorraine Nicol, Irrigation Water Murkets in Somthern Alberta (M.A. Thesis, University of Lethbridge, 2005) [unpublished].

Nicol's study deses not deal with the assignment procedure under the Water Aer nor with other forms of derivative rights available under the IDA, supra nole 2.

C.G. Veljanovksi, "The New Law-and-Economics: $\wedge$ Research Review" in A.l. Ogus \& C.G. Veljanovski, eds., Readings in the Economics of law and Regulation (Oxford: Clarendon Press, 1984), 12 at 20.

K. William Easter, Ariel Dinar \& Mark W. Rosegrant, "Water Markets: Transaction Costs and Institutional Options" in Markets for Water, supra note 19, 1 at 4-5.

Easter, Rosegrant \& Dinar, "Perlormance of Water Markets," supra note 22 at 301-302. 
over quantities and timing of transfers. Policy-induced transaction costs are those costs imposed by legal and institutional requirements such as the need for prior approvals that seek to avoid injury to third parties and the natural environment. Clearly one would expect transaction costs to be higher in formal water markets than in informal water markets.

\section{Tie Benefits of Water Transfer and Marketing Rfgimes}

In assessing the costs and benefits of water transfer and marketing regimes it is important to emphasize that this is a comparative exercise (i.e., we are assessing the performance of transfer regimes against other possible methods of allocating or reallocating resources such as command and control methods). A key argument in favour of market-based transfer regimes is that they provide incentives to both buyers and sellers to conserve water. Command and control methods do not provide this internal dynamic. Instead, government allocations will likely prove inefficient, favouring (for political reasons) low value uses such as irrigated agriculture rather than altemative higher value industrial and municipal uses. ${ }^{30}$

Other economic policy tools (such as water pricing) may also encourage conservation but may have distributional implications that make their adoption politically infeasible. Easter et al. ${ }^{31}$ emphasize, for example, that water pricing will always detrimentally affect current users (who must now pay to use what they had previously treated as a free input) but a market in which the initial distribution respects existing entitlements ensures that the incumbents will benefit from subsequent transfers. It is therefore likely that a government will find it much easier to realize the advantages of market-based policy approaches by introducing water transfers rather than water pricing.

\section{The "Costs" of WATER Transfer Regines}

Some of the objections to water transfer and marketing regimes are based upon the proposition that water is an essential public good quite unlike other commodities. ${ }^{32}$ Other objections focus on such issues as the social and environmental effects of permitting water transfers.

" For example, Easter, Ruscgrant, \& Dinar, "Perlormance of Water Markets," supra note 22 at 299-300. See also Theodore M. Horbulyk \& Lynda J. Lo, "Wellare Gains from Polential Waler Markets in Alberta, Canada" in Markets for Waler, supra note 19,241 (assessing the potential welfare gains that might result from permitting transfers but also considering the implications of different initial distributions of the resourec).

Sce, e.g., Edith Brown Weiss, "Water Transfers and Internalional l.aw" in Fresh Water. supra note 18. 61 at 61 : "Iresh water is vitul to human life and to the sustainability of Earth. There is no known substitute for frestiwaler. People have strong emotional ties to water whether for health, nature, soil productivity, religious or other reasons"; und Substantive Assmes Arising in the Implementation of the International Covenam on Economic. Social and Culmural Rights, UN IESCOR, 29th Sess., General Comment No. 15. UN Due. F/C.12/2002/11 (20102), online: Office of the United Nations High Commissioner for Human Rights < www.unhelir.ch/html/menu2/6/gc 15.doc>. For critical comment see Stephen C. MeCaffrcy. "The Iluman Right to Water" in Fresh Water, supra nole 18, 93. Sax, supra note 20 emphasizes that water is a community resource, not a mere commodity, and that two-party trades need also to take into account the effect of that trade on the community interest. 
Arguments based upon the unique nature of water are, at bottom, ethical arguments. They assert that some allocation questions are so important (other examples might include health care, education, and other forms of social "rights") that we should not leave them to the market. Others respond with the argument that if the resource is not subject to market forces then users will not value the resource and will have no incentive to conserve.

Objections to water transfers are frequently based upon the social and economic implications of large scale water transfers (or the cumulative effect of a series of smaller transfers) offering a version of what is known as the "death spiral" in public utility regulation. Bjomland and McKay offer the following summary of the effects of "dewatering" communities: ${ }^{33}(1)$ net profits in the farming sector will be reduced causing a decreased taxation base; (2) this will have follow-on effects in the service and processing sectors; (3) property values will decline, further eroding the taxation base for necessary local infrastructure; (4) the area will suffer population declines undermining the viability of essential community services (schools, hospitals, public transport); (5) the cost of maintaining irrigation infrastructure (storage and canals) will increase for those remaining on the system; (6) uncultivated land harbours pests and weeds affecting neighbouring properties; and (7) the region loses its productive base, way of life, and local culture.

Environmental concerns with water transfers frequently emphasize the problem of socalled sleeper and dozer rights. These are rights that are not used up to the full level of the licensed amount. The creation of a market provides an incentive for the licensee to transfer its entitlement with the transferee inevitably making more intensive use of the water right with the necessary implication that there will be less water left for the aquatic environment. ${ }^{34}$ But even where existing rights are fully utilized (i.e., the right is not a sleeper right), there will still be an incentive to conserve and intensify the use of water. While this may be socially desirable and lead to the adoption of more efficient irrigation systems, it may also lead to the loss of wetland and riparian habitat as water users seek to reduce canal losses, etc. Greater efficiency may also reduce return flows on which other users depend. Intensification of use and reduced return flows may also have a detrimental impact on water quality. ${ }^{35}$

The literature identifies various mitigative strategies that may be used to overcome some of the social, economic, and environmental concerns associated with transfers. These include prohibitions (or serious restrictions) on inter-basin transfers, requirements for prior approval of transfers, no-harm analyses prior to approval, prescribed limits on the proportion of water that may be transferred, restricting transfers to amounts actually used or consumed, the prescription of appropriate ground rules (such as instream flow and lake level requirements)

$13 \quad$ Henning Bjornlund \& Jennifer M. McKay, "Overeoming the Introspective Legacy of Tradeable Water Entitlement Policies in South Eastern Australia" in Just \& Netanyahu, supra note 22, 315 at 328 . See also Saralt lf. Bates ed al. Searching Ow the Headwoters: Change and Rediscoweng in Wastern Water Policy (Washington, D.C.: Island l'ress, 1993) esp. at 84-85, 156-58. The "death spiral" is said to occur when we allow industrial consumers to direet contract and leave the utility's system, leaving those on the syslem shouldering an increasing share ol the costs thereby creating a greater incentive for them to find an exit as well.

35 Marie Leigh Livingston, "Institutional Requisites for Efficient Watcr Markets" in Markets for Water, supro note 19, 19 at 29-30. 
to protect important public values, and allowing conservation organizations and others to use the transfer system to acquire instream flow rights to protect the aquatic environment. ${ }^{36}$

\section{E. THIRD-PARTY EFFECTS}

Beyond the broader environmental and more general social and economic effects of transfers, the literature also discusses what are generally referred to as third-party effects, i.e., the effect of the proposed transfer on junior rights holders. Gould identifies some seven examples of third-party effects (although his seventh category refers to impacts on persons other than junior rights holders which we have discussed in the last section). ${ }^{37}$ Gould's list is as follows: ( 1 ) reduced return flows (or an increase in consumption by the transferee leaves less water in the stream for other appropriators); (2) transfers of seasonal rights (may change the timing of diversions to a high demand period and may also change the total amount diverted); (3) stream conveyance losses (a change in the point of diversion may increase channel losses); (4) changes in the point of diversion (a downstream transfer of a senior right may have an impact on a junior right located between the original diversion point and the new diversion point); (5) temporary storage problems (noting that, while most uses provide return flows, the timing of these flows may be an important asset since delays in returns may produce benefits by providing notional storage and therefore deliveries in later, low-flow periods); (6) changes in quality; and (7) injuries to non-appropriators (social and economic impacts on communities).

Gould notes that state water legislation in the United States is designed to ensure that a proposed transfer will have no detrimental impact upon junior rights holders. This may lead the relevant decision maker to limit the amount of water that can be transferred to the transferor's consumptive entitlement rather than its diversionary entillement although, as Gould recognizes, this will not deal with impacts associated with timing variations.

\section{F. The Role of Water USE ASSOCiations}

Much of the literature emphasizes the importance of water use associations (WUAs) such as irrigation districts, especially in the context of the development of informal markets. ${ }^{3 .}$ WUAs may be important in making the necessary improvements in conveyance systems to achieve greater efficiencies. WUAs may also facilitate the development of efficient markets by, imer alia, brokering trades (thereby reducing transaction costs) and by reviewing proposed trades to ensure that they do not impose uncompensated externalities on other users. $^{39}$

Sax, supra note 20 emphasizes that water in place is a type of wealth that accrues not just to the owner of the water right but more generally to the comnunity. When waler is sold as a commodity only the formal owner of the resource is compensated but others sufter harm from such transfers. To respond to these concerns Sax suggests that: (1) we should favour sales that minimize disadvantages to the community (c.g., Iransfers made possible through conservation that still allows economic activity in the selling community); (2) apply a transfer tax to kecp the community whole and counter the redistributive effects of the transfer.

Gould, supra note 16.

Livingston, supra note 35 .

lbid. al 25. 


\section{G. Not Trusting The MARKeT}

Finally, some of the literature refers to the tendency of governments to undermine the development of a market in water rights by intervening in drought years to impose alternative allocations. Livingston, for example, refers to cases of administrative rationing and to compulsory transfers from agriculture to cities during droughts. ${ }^{40}$ While interventions of this sort serve to solve a particular problem, they create the expectation of future government intervention, thereby impairing the development of the allocative function of the market.

We can now turn to an analysis of the rights available under the Water Act and their transferability. I shall return to these themes in the concluding section of the article.

\section{RIGHTS AVAILABLE UNDER THE WATER ACT}

In this Part we shall consider two forms of rights, water licences and the rights of traditional agricultural users."

\section{A. WATER LICENCE}

For the purposes of this discussion a "water licence" refers to a water licence that has been issued after 1 January 1999 when the new Water Act came into force, but also includes the so-called "deemed licences," which embraces all manner of licences and approvals issued under the terms of the former Water Resources $A c f^{42}$ or any other predecessor $A c t{ }^{43}$

\section{WHAT DOLS THI ENTITLEMENT AUTHORIZE?}

A licence authorizes the diversion of a specified volume of water for one or more of the purposes prescribed in the regulations and stipulated in the licence. ${ }^{44}$ When a licence is issued, "the Director must specify in the licence the land or undertaking to which the licence is appurtenant" ( $\mathrm{s} .58$ ). The current $\mathrm{Act}$ contemplates that a person will acquire a preliminary certificate before acquiring a licence. The preliminary certificate may be issued subject to any terms and conditions. ${ }^{45}$ The applicant may have to fulfill some of those terms and conditions prior to obtaining a licence, but the preliminary certificate must also stipulate those terms and conditions that will carry through into the licence (s. $66(4)(\mathrm{b})(\mathrm{i}))$. In some

to $\quad$ bid. at 26 .

$\$$ This is not to suggest that these are the only forms of entitlements available under the Water Act. Other forms of entitlement include: household user entitlements (s.21) and exempted agricultural users (s. 19).

12 Supra note 10.

43 Water Act, supra note I, s. I8(1).

st This follows from ss. 49(1) and 68(2) of the $A c t$ and s. 11 of the Water (Ministerial) Regulation, Alta. Keg. 205/1998. Scction 11 provides that a licence may be issued lor any or all of the following purposes: municipal, agricultural, irrigation, commercial, industrial, water power, dewalering, management or'fish, management of wildlife, implementing a water conservation objective, habitat enhancement, recreation. and water management. The order of listing does not confer any priority. This list concludes with a basket clause: "any other purpose specified by the Director."

ts Supra note 1, s. 66(3). While this is a broad discretion, the power is at least limited by the purposes (s. 2) of the Act. For a discussion of the interpretive role of the purposes clause of the Act, see Nigel Bankes, "Shining a Light on the Management of Water Resources: The Role of an Environmental Appeal Board“" (2006) 16 J. Envtl. L. \& Prac. 131. 
cases these terms and conditions may affect the volume of water that the licensec is authorized to divert, either to protect the aquatic environment, or to meet some other value. such as fulfilling apportionment obligations to Saskatchewan under the terms of the master apportionment agreement. ${ }^{46}$

\section{What IS THE PRIORITY OF A LICLNSLE?}

The priority of a licensee is determined according to the number assigned to the licence on registration. This in turn is determined in accordance with the date and time of application for the licence or preliminary certificate. ${ }^{47}$ Priority is relevant $v i s-\dot{a}$-vis other licensees and traditional agricultural users but not vis-à-vis household users (who therefore effectively have a senior priority). Under the priority scheme of the $A c t$, a senjor rights holder has the right during a time of scarcity to divert the whole specified allocation of water before a junior licensee or registered traditional agricultural user has any right to divert (s. 30(2)).

\section{What IS THE DURATION OF A LICENCE?}

Section $51(5)$ of the new Acr requires the Director to include an expiry date in any licence issued under the $A c t$ and determined in accordance with the regulations. ${ }^{48}$ This was not a requirement under the predecessor versions of the Act. Accordingly, older licences were typically issued without term and these deemed licences will therefore continue in perpetuity (unless terminated for cause) since they are not subject to the renewal provisions of the Act. ${ }^{+9}$ Sections $59-61$ of the Act govern renewals. Several elements of these provisions are important to the security of the interest held by the licensee. Perhaps the most important ${ }^{50}$ is that the Director may only refuse to renew a licence on certain specified grounds including: public interest, inconsistency with an approved water management plan, the need to meet a water conservation objective, significant adverse effect on the aquatic environment, or nonuser of the licence.

Prairie Provinces Water Board, The 1969 Master Agreemem on Apporfiomment and B!-Lan's. Rules and Procedures (as amended October 2003). online: Institulc of Intergovemmental Relations <www. iigr.ca/pdf/documents/1348_Master_Agreement_on_App.pdf $>$.

b) Supra note 1, ss. $27-30$ and. in relation to preliminary ecrtificates that lead to the issuance of a licence. see s. 66(4).

Section 12 of the Water (Ministerial) Regulation, supra nole 44, deals with the selting of expiration dates and the rules are as follows: (1) where there is an applicable approved water management plan. an order of the Minister, or a water guideline that specifies an expiry date or how such a date should be determined the Director must apply that plan etc.; (2) if there is no relevant plan etc., the Dirtector must issue a licence with an expiration date of ten years (less if the applicant has applied for less or if, in the Director's view, the expected duration of the project is less; more if the Director believes this to be justified in light of a set of criteria): and (3) if there is no relevant plan efc., but the licence is to be issued for municipal, agricultural. irrigation, or water conservation objective purposes, then there is a presumption that the licence will be issucd for 25 years subject to the considerations referred to in (2). The criteria relevant to an extended term are as follows: applicable plans and guidelines, purpose of the licence, area of the Province, lifespan of relevant technology, duration of project, polential social and economic impact, potential impact on the aquatic environment. policics and guidelines, and any other matter the Director considers relevant.

so Sce also ibid., s. 59(3), which suggests that generally the licence of a licensee who fails to make an application for a renewal will expire. 
A renewed licence has the same priority as the original licence. The $A c t$ is largely silent on the question of whether or not the Director may impose new terms or conditions as part of a licence renewal. The only specific reference is s. 59(6), which provides that, where the Director fails to provide notice of a right of renewal prior to its expiry date, the licence will be automatically renewed for a one year period "on the same terms and conditions."

In sum, the licence is the largest form of right available under the Water Act. Older licences confer the highest priority. Licences issued under the new Act must be issued for a term. New licences are renewable and there is an entitlement to a renewal unless the application falls within certain conditions. The most significant licences, in terms of volume and priority, pre-date the new Act and were issued in perpetuity, many to the province's 13 irrigation districts.

\section{B. Registered Traditional Agricultural USER}

Notwithstanding its name, the traditional agricultural user is a new form of right introduced by the current Water $A c t$ in 1999. The term refers to a person ${ }^{51}$ who, prior to the Act coming into force, diverted water for traditional agricultural purposes and who, prior to 31 December 2001, made an application to register that use in accordance with ss. 73-78 of the $A c t$.

\section{What Does the EnTITLEMENT Authorize?}

A registered traditional agricultural user (RTAU) may commence and continue the diversion of water from the sources authorized in the registration for the purpose of raising animals or applying pesticides to crops, as part of a farm unit, as authorized by the registration, and up to a maximum of 6250 cubic metres of water per year. ${ }^{52}$ The registration must specify the land to which the registration is appurtenant and specify the sources from which water may be diverted. ${ }^{53} \mathrm{~A}$ registration is stated to be: (a) appurtenant to the land specified in the registration; (b) inseparable from the land specified in the registration; and (c) runs with the land on its disposition unless the Lieutenant Governor in Council otherwise orders. $^{54}$ The rights of a RTAU may be enjoyed in conjunction with an entitlement that the same person may have as an exempted agricultural user under s. $19 .^{55}$

\section{WIIAT IS THE PRIORITY OF A RTAU?}

The priority that the $A c t$ affords to a RTAU is essentially the same as the priority afforded to a licensee provided that the user of the right in the period immediately following the entry

That person must be an owner in liee simple or the occupant of unpatented Crown land, which land in either case adjoins a river, stream, lake, natural watercourse or other natural water body, or under which groundwater exists (s. 73).

55. Section 25 of the Water Act makes it clear that these entitlements are cumulative. 
into force of the $A C l$ applied for a registration (i.e., prior to 31 December 2001). ${ }^{\text {sh }}$ The actual priority assigned is the date of the first known date of diversion of water for agricultural purposes "from the sources of water on the land specified in the application." been no such application, a person who diverted water for raising animals or other farm related purposes may continue to do so but as an exempted agricultural user under s. 19(1) of the $A C l$ and without the benefit of any priority.

\section{WHAT IS THE DURATION OF A RTAU?}

Section 74(2) contains the simple statement that "[a] registration is effected without an expiry date." Once issued, there are very few options available to the Director to amend or cancel the registration. Thus, a registration cannot be cancelled because of concerns as to the aquatic environment but only for such reasons as non-payment of fees or "if there is an emergency or if, in the Director's opinion, it is necessary for public safety purposes."

In sum, the new $A c t$ created a new form of right to recognize the historical practices of agricultural users in the province. In effect, the government recognized and incorporated a new form of water right based upon actual historical prior appropriation ${ }^{50}$ that had continued to run in parallel with the licensed prior appropriation system that had long been the hallmark of western Canadian water law. ${ }^{61}$ The priority of this new form of right is traced not to the date of registration but to the date of first appropriation. The right is particularly robust since, in common with the older deemed licences, it is not subject to the licence renewal provisions of the new $A c t$.

\section{THE TRANSFERABILITY OF ENTITLEMENTS UNDER THE, WATER ACT}

The Waser Act contemplates two methods by which another person may acquire water or water rights from an existing water rights holder: (1) an agreement to "temporarily" assign water under s. 33 of the $A c t$; and (2) transfers (permanent or for a term) of an allocation of water under ss. $81-83$ of the $\mathrm{Act}$. For the purpose of completeness it is important to mention a third, and more traditional, means of acquiring a water right which was, of course, to purchase the land to which an existing water right was appurtenant. ${ }^{61}$

Sec, in addition, s. 76 of the Woter ACt, which allows a person to appeal the priority number of a registration to the Court of Queen's Bench. The appeal must be launched within five years of the effective date of the registration.

57

58

59

en

01

Supra note 1. s. 28.

Ibid., s. 78(I)(c).

This of course is the norm in the western United States.

It is a testament to the political power of the agricultural lobby that these users were able to secure state endorsement of these practices and to secure a priorily based not on a paper registration (which the Act had long required) but on prior use.

Prior lo the new Act, water rights were not severable from their appurtenant land and were, therefore. only transferable as part of the sale of the land. Indeed, it seems safe to say that since they were appurenant they had to be translerred as part of a transfer of the land. The transferee could not reserve the water licence from the transfer unless the transferor was relaining a part of the appurtenant lands, in which case an application might be made to split the licence: Water Resources Act, supra note 10, s. S5 ("apportionment of water and water charges"). As might be expected, the new' $A c t$ has not interlered with this method of "transferring" water entitlements. Indeed, it is hardly something that the Act needs to address at all, and the only relevant provision seems to be s. 54(1)(a)(iv), which authorizes the Director to amend a licence on his or her own motion "if the Director has received notice of a disposition 
The following section examines the statutory framework for each of these two new methods of effecting a "transfer." For each form of "transfer" I examine the scope of public review by regulatory authorities, as well as such factors as the duration of the "transfer" and any relevant restrictions.

The $A c t$ contemplates, in $\mathrm{s.} 33(1)$, that both a licensee and a traditional user may agree to assign "all or part of the water" that the licensec or RTAU is entitled to divert under its licence or registration. By contrast, the $A c t$ provides that only a licensee may use the transfer provisions of the $A c t^{62}$

\section{ASSIGNMENTS}

In brief, an agreement to assign water is a mechanism by which a licensee or RTAU may allow another existing licensee or RTAU to take the benefit of the assignor's entitlement for a temporary period. In principle, the assignment may be used to avert a temporary crisis (e.g., a need to get water on to a specialty crop within the space of hours or days) or might be used on a seasonal basis where snowpack assessments suggest that flows will be inadequate to meet all irrigation needs during the irrigation season.

\section{THE SCOPE OF THE REVIEW}

The $A c t$ does not require prior approval for an assignment. ${ }^{63}$ Indeed, far from contemplating prior approval, the $A c t$ merely requires that the parties submit a copy of the agreement to the Director "on the request of the Director." Instead of a regulatory review, the $A c t$ requires the parties to conduct their own assessment of the effects of an assignment insofar as s. 33 stipulates that the parties can only enter into the agreement "if," inter alia, there will be no adverse effects on persons with senior rights or a household user, or "any water body or the aquatic environment."6s This is a tall order and it seems somewhat peculiar to thrust this public responsibility onto the parties to the agreement. ${ }^{\text {th }}$

of land or an undertaking to which a licence is appurtenant, to reflect the disposition." These forms of "transfer" will not be discussed further in this article.

Supra note $1, \mathrm{~s} .82(4)(\mathrm{c})$, stipulates that the following allocations of water cannot be transferred: a licence for a temporary diversion. houschold purpose. RTAU registration, preliminary certificate, and rights to divert held under an approval. An approval generally authorizes works or other activities that affect a water body: it does not itself provide the right to use water.

Section 33 of the Water $A$ ct opens with the words. "A licensee or traditional agricultural user may. subject to the regulations" [emphasis added]. It is therefore conceivable that the regulations might be used to at least require notification although at present the regulations do not address assignments. Thompson, supra note 5 at 5 provides some background on the rationale for $\mathrm{s} .33$ of the Act. According to this account, prior to 1996 (the date the new $A c$ was passed although not proclaimed until 1999) there were several examples in which water users in water-short years decided to share water proportionately rather than relying on the priority system. This section of the ACt was intended to regularize those informal practices.

Supra note 1, s. 33(1)(n. 13ut at present there is nothing that requires the parties even to give notice to the Director of an agrecment to assign water, so it is not clear how the Director is in a position to request a copy.

to It may also have some drafting implications for those who might be concerned with the enforceability of such agreements. Drafters might want to provide a series of preambular statements satisfying each of the conditional "if" statements of s. 33(1): e.g., "Whereas the parties to the agreement are satisfied that the assignment of water provided for by this agrecment will not cause an adverse effect on any water 
The section goes on to cast the Director in the position of second-guessing, if necessary, the assessment of the parties to the agreement. Section 33(5) contemplates that, where the Director forms the opinion that an assignment causes or may cause an adverse effect on an interest referred to above, "the Director may direct that water must not be diverted under the agreement or a subsequent agreement, either permanently or for a specified period of time."

This review provision is not free of difficulty on both procedural and substantive grounds. On procedural grounds, the issue might be put as follows: does the Director have an obligation to provide notice to the parties to the agreement and other affected parties of his or her intention to provide this "direction" and afford them the opportunity to make submissions before he or she exercises the statutory discretion? The argument in favour of implying such a requirement is that by this time there is already in place an enforceable agreement between the parties, presumably executed for valuable consideration. The issuance of such a "direction" effectively prohibits the parties from acting on the agreement and therefore interferes with vested rights. The relevant case law suggests that an affected party should be entitled to a relatively high degree of procedural protection in this sort of situation unless the $A c t$ explicitly stipulates otherwise. ${ }^{67}$

The argument against the availability of procedural protection would focus on this last proviso and argue that the $A c t$, at least implicitly, denies the availability of procedural safeguards. This is because (or so the argument will run), the $A c s$ provides a clear statement of those circumstances in which the Director has to give notice of his or her decisions (ss. 110-113) with the implication that the Director need not give notice in other cases not covered by the statutory list. A possible response to this argument is that, while the statute prescribes the notice requirements for decisions, it is silent on the notice requirements for "directions" and that, therefore, this category of statutory discretionary powers should be governed by the usual rules on procedural faimess.

My assessment of the competing arguments is that the parties to any such agreement would be entitled to notice and the right to make submissions before the Director issued a direction.

There are also at least a couple of problems at a substantive level with the provision. First, there is some uncertainty as to what a "direction" under the $A c t$ is, or what might be the legal effect of a direction. The Act generally does not use the term "direction" when it requires a

body or the aquatic environment," etc. Perhaps more significantly the section oflers no protection to jumior rights lolders who may be adversely affected by the agreement and yet the literature on thirdparty effects (see Gould, supra note 16) certainly suggests that junior rights holders may suffer significant adverse effects as a result of changes to points of diversion, use, flow, and seasonal demands and it hardly seems to the point that such changes may be temporary - especially if such agreements were renewed in suecessive waler-short years.

6? Sec, e.g., Knight v. Indian Head School Division No. 19. [ I990)] I S.C.R. 653, an employment case but suggesting three relevant factors in deciding whether a duty to acl fairly is required: (1) the nature of the decision (is it final, is it specific, does it terminate a relationship?): (2) the relationship between the decision maker and the person affected (e.g., is it an office "at pleasure"?); and (3) the effect of the decision on the individual's rights (is the decision an important one that will have a signilicant impact?). An emergency situation might mitigate what would otherwise be a requirement for prior notice and an opportunity to make representations. 
person to do something. It more commonly uses the term "order." ${ }^{\text {"6x }}$ It is true that s. 33(6) provides an internal definition of the term since it states that where the Director has issued a direction, the water must not be so diverted. But this merely pushes the analysis one step further back..$^{69}$ Second, even if one assumes that the "direction" is issued to the parties to the original agreement (who should all be readily identifiable) what is a "subsequent agreement"? It seems clear that an agreement between exactly the same parties will be a subsequent agreement but what about an agreement that involves some of these parties but not others? In short, the procedure for post-hoc review of agreements to assign water seems fraught with difficulties that may make it hard for the Director to discharge his or her public interest mandate.

Finally, it bears emphasizing that, unlike the position with respect to transfers, no party will have an opportunity to appeal decisions with respect to assignments to the Environmental Appeal Board (EAB). This is because the EAB's jurisdiction is purely statutory and none of the relevant decisions (by either the private parties involved or the Director) will serve to trigger an appeal right."

\section{THE DURATION OF: AN ASSIGinMENT}

The opening language of s. 33 authorizes the assignors to "temporarily assign" water "for a period of time set out in an agreement." The balance of the section contains no less than seven references to the assignment as a "temporary assignment" or to "temporarily assigning" or "temporarily receiving" water under the agreement. However, the $A c t$ at no point defines the term "temporary." What then does the $A c t$ mean by this term? The general interpretive rule is that, absent some specialized definition, the words in a statute bear their ordinary grammatical meaning. The Shorter Oxford English Dictionary suggests that the principal definition of the term is that of lasting for a limited time, transient, made to supply a passing need." But while this conlirms that this is something less than permanent, it does not really help us decide whether this means that an agreement to assign should be confined to a single irrigation season or might extend beyond that.

Perhaps the most we can say is that where such an agreement extends beyond a single year, the greater the risk that it will prove to be unenforceable. ${ }^{72}$ But this is just one type of interpretive problem in the context of duration. Consider also the possibility of a junior licensee seeking to enter into a multi-year contingent contract under s. 33 designed to allow

ar See generally, supra note 1, ss. 97-104, dealing with Water Management Orders.

(2) It is certainly not an offence since $\mathbf{5 .} 33$ is not listed in s. 142. It might be possible for the Director to issue a water management order but in order to do so the Director would have to comply with the procedural requirements applying to such orders. The Director might also be able to issue an enforcement order under s. 135.

so See supra note 1, s. 115 . See generally, Bankes, supra note 45.

" 3d ed., s.v. "temporary."

$\because \quad 1$ frame the issue in terms of enforceability because there is nothing in the Act that purports to make nonlemporary assignments of water void. Even ss. 33(5) and (6), which deal with the Director's discretionary powers to direct that there be no assigninents permanently or for a specified period, do not prohibit future agrements; they merely stipulate that no water may be transferred under sucl an agreement. Such a direction could provide the foundation for an enforcement order under the Act (sitpra note 68$)$ and would cause a court to refust an application from the assignee for an order of specific performance. 
it to make a call on a senior licensee in order to shore up its security of supply in a low flow year. Will such an agreement be enforceable? Again, it is hard to come to a firm conclusion. $^{3}$

\section{OTHER RESTRICTIONS ON ASSIGNMENTS}

Section 33 contemplates three forms of restrictions on assignments. These restrictions relate to: (1) who qualifies as an assignee; (2) the means by which the assignee must be able to take delivery of the assigned water; and (3) the volume of water that an assignee is permitted to receive under an assignment.

First, the assignee must be "another licensee or traditional agriculture user." the Director has issued a s. 53 order imposing a moratorium on new licences, the assignment provisions cannot benefit a new entrant since, by definition, such a person will not be an existing RTAU or licensee. But if our assignee has a licence, the assignee can acquire water from any RTAU or licensee on the watercourse no matter what the authorized purpose for diversions under that licence. This follows from s. 33(3)(b) which provides that "the diversion" under an assignment "must be done in accordance with the licence or registration of the licensee or traditional agriculture user receiving the water. ${ }^{" 75}$ While one might argue that this is simply a necessary condition and not a sufficient condition (and that therefore the purposes of the assignor's and assignee's interests must also coincide since otherwise we are effecting a de facto amendment to the purpose of the licence), the better view is that the only purpose that is relevant is the purpose of the transferee. We can explain this conceptually by suggesting that the assignee's diversion is a diversion that occurs under the assignee's licence or registration and not pursuant to the assignor's. ${ }^{\text {th }}$

Second, the person receiving the water must be "able to access the assigned water as a result of the natural flow or natural presence of the water." This condition suggests that parties cannot proceed by way of an assignment if new works would be required to give effect to the assignment. ${ }^{78}$ This is consistent with the temporary nature of the assignment.

"Note that such an arrangement, even if enforceable, might still prove to be problematic from a risk management perspective given the Director's exceptional powers under ss. 33(5) and (6) lo suspend for a tixed period, or permanently, any assignments. In short. even if the lawyers for a potential assignee were to conclude that the agreement would be enforceable, the partics would still bear the risk that at some future time the Director might suspend its entitlements. The resulting secnario would presumably be governed by the law of frustrated contracts unless the parties had addressed this contingency in their own agrecment. It seems unlikely that an assignor would provide an unconditional commitment to make additional water available. In practice, this will leave the risk of non-perfornance as a result of a Director's decision with the assignee.

3 Supro note I, s. 3.3(1).

3 Ihid., s. 33(3)(b) [emplaasis added].

;o This conecptualization also allows us to avoid the appurtenancy rules of the Act and especially the rather ominous language of s. $75(2)(\mathrm{b})$. which instructs us that a registralion "is inscparable Irom the land specified in the registration."

$\because \quad$ Supra note 1. s. 33(1)(d).

ix Or at least this is one interpretation of the provision. The use of the word "natural" serems somewhat awkward. Surely it was not intended to preclude an assignee taking water from an irrigation ditch or canal. 
Third, s. 33(3)(c) provides that the assignee "must not divert a total amount of water that is greater than the allocation of water specified in the licence or registration" of the person "receiving the water" (i.e., the assignee). This condition confirms that an assignment cannot be used by an assignee to acquire new rights in the sense of a greater quantity of water but that it can be used to firm-up an existing entitlement. In effect, an assignment can be used to better the priority of the assignee. To take an analogy from the pipeline business, a s. 33 assignment allows a low priority licensee with an interruptible entitlement to convert its interruptible supply to a firm supply.

Finally, and as one might expect, the assignment provisions of the statute include a "no double dipping" rule to the effect that the assignor "is not entitled to divert the allocation of water that has been temporarily assigned" (s. 33(3)(a)).

\section{EXAMPLE OF A SECtion 33 AgReEMENT to ASSIGN WATER}

Since s. 33 agreements do not require public approval or notice, there is no public record of such agreements. However, the literature does refer to at least one important example. This is the assignment agreement of 2001 involving many licensees in the three southern tributaries of the Oldman River (Belly, Waterton, and St. Mary Rivers). ${ }^{79}$ In that case, snowpack and storage information made available to parties suggested that licences with a post-1950 priority date would have to be curtailed. Some of these licensees included important new food processing plants who would be significant purchasers of irrigated crops such as potatoes. In light of this, licensees on the three southern tributaries including seven irrigation districts, private irrigators, municipalities, and industrial users agreed to a proportional sharing, each accepting about 50 percent of their entitlements although later precipitation resulted in this being adjusted to about 60 percent. In other words, rather than relying upon the statutory system of priorities, water users agreed to share the available water thereby rejecting, at least temporarily, not only market-based solutions to the problem of scarcity but also the fundamental premises of the licensed prior appropriation system. Government played a key role in facilitating the agreement and agreed to help administer the sharing agreement.

\section{Can an IrRigation District Be a Party to a Section 33 assignment?}

There is nothing in the Water Act that precludes an ID from becoming a party to a s. 33 agreement. One would therefore assume that, as a licensec, an ID would indeed be able to enter into such an agreement and, as the above practice suggests, IDs appear to have done so. The $I D A^{810}$ is also completely silent on the capacity (or otherwise) of an ID to enter into an agreement under s. 33 of the Water Act for the temporary assignment of water, either as an assignor or as an assignee. Here we encounter a problem. In Part IV of the article we explore in detail the various types of agreements that an ID may enter into for the supply of water to others. Suffice it to say, for present purposes, the $I D A$ prescribes the terms and conditions and forms of agreement by which any party may acquire a water entitlement from an ID. By implication, these are the only ways in which a party may acquire rights from an 
ID. Since the IDA does not deal with agreements to assign under s. 33 of the Water $A c t$ as a special category of $I D A$ agreement, it would seem that an ID can only enter into an agreement to assign water and can only be bound by such an agreement to the extent that: (1) the terms of the agreement also fall within one of the prescribed categories of the IDA agreement; and (2) the ID has followed any necessary procedure for the approval for such prescribed agreements. I shall revisit this question in Part III of the article dealing with the IDA.

We can now turn to examine the second method that the Water Act introduced to permit the reallocation of water resources, namely transfers.

\section{E. Transfers}

In brief, a transfer is a formal arrangement subject to governmental review and approval by which a person (the transferee) may acquire all or part of the water right of a licensee either absolutely or for a term.

\section{THE SCOPE OF REVIEW}

The statutory scheme for transfers (ss. 81-83) is both more complex and more prescriptive than the scheme for agreements to assign water. The $\mathrm{ACl}$ contemplates that an application may be made for a transfer of an allocation of water under a licence. The application need not be made by the licensee but will require that person's consent. ${ }^{81}$ The Department takes the view that the transfer mechanism may be used to change the appurtenancy of a water licence even though the transferee may be the same person. ${ }^{{ }^{2}}$ This seems in accord with the $A C t$ since the term "transfer" refers to the transfer of the right from one appurtenant piece of land to another. Once transferred, the new licence will run with that new appurtenant piece of land. ${ }^{{ }^{3}}$ It seems that it is also possible to use the transfer procedure to "transfer" a licence from one waterbody to another where the transferee does not change and the proposed use does not change. ${ }^{84}$ This was the case in a successful application brought by the Town of

Thus the application may be made by the transferee and. given the Iransaction costs involved, the transferor may want the transferee to assume these responsibilities.

4: Where the lands of the licensee are contiguous, the Department believes that the change might be effected by a s. 54 amendment (presumably under $s .54(1)(b)(v)$ to change the point of use or add a point of use). See Alberta Environment, Administrative (iuideline for Transferring Water Allocations (revised 26 August 2003) at 4, online: Alberta Environment <www3.gov.ab.ca/env/water/ Icgislation/Guidelines/Transfer_Guidelines.pd $\gg$ [Administrative Gurdeline]. The Guideline also defines the term "contiguous land-ownership unil" to mean "all lands associated with the farm or business physically linked, including lands separated by road. canal. water body. road allowance or rail line, but not lands separaled by land owned hy another person. Physically linked also includes lands diagonally opposite the corner of an intersection" (at 4). In some cases it may not matter whether an applicant proceeds under $\mathrm{s} .54$ or $\mathrm{s} .81$ of the $\mathrm{Act}$, but in others cases it will: however, the procedures for licence transfers are far more rigorous than those for licence amendments (e.ge. no need for a certificate of good standing). Note as well that the Direclor does not need to have a water management plan in place before proceeding with a licence amendment. that land on any disposition "unless the Lieutenant Governor in Council orders otherwise."

When I first looked at this scenario my initial reaction was that this fell outside the ambit of's. 81 transfer procedure, and that it was better classificd as an application to change a point of diversion from one stream to another or an abandonment of one right and an applieation for a new right. However, if the 
Cardston. In that case, Cardston applied to transfer a portion of its existing water right from Lee Creek, a tributary of the St. Mary River, to a new point of diversion on the St. Mary River downstream of its confluence with Lee Creek. ${ }^{85}$

The statutory scheme contemplates a number of different steps: (1) an application to the Director; (2) a public review by the Director of the proposed transfer "in a form and manner that the Director considers appropriate"; ${ }^{86}(3)$ a decision about whether to grant or deny the application along with any relevant terms and conditions; and (4) a decision as to whether or not to require a conservation holdback. The Department has issued an Administrative Guideline to provide information and to establish a consistent methodology for dealing with transfer applications. ${ }^{87}$ Further guidance may also be obtained by examining the Director's Decision Statements in those applications that have been approved to date. ${ }^{88}$

\section{a. An Application to the Director}

An application to transfer an allocation of water must be in the prescribed form. ${ }^{89}$ and be accompanied by the prescribed fees and information. The information required includes: information about the proposed new point of diversion, the proposed use, and the rate of diversion and annual quantity; a plan showing the proposed new works; and, if the transfer is for irrigation purposes, an agricultural feasibility report. The Director may require an applicant to submit additional information in support of the application.

The $A c t$ also imposes a series of conditions precedent that must be met even before the Director can consider an application (s. 81(7)). The most important of these are that: (1) there be in place an approved water management plan for the relevant part of the province and that that plan authorizes transfers; ${ }^{20}$ and (2) the allocation of water to be transferred is held under a licence in good standing."

transferee were a different person we would have no difficulty calegorizing this as a transfer of a water right from a tributary to the mainstem and it is hard to see why a licencee "transferting" to itself should be trealed liss favourably than any other transferee.

Decision Stalement: Transfer of Water Allocation by the Town of Cardston from Lec Creck to the Si. Mary River, 20 September 2004 [Cardston Transfer].

Supra nolt 1, s. 7(3).

Administrative Guideline, supra note 82. The Water Act, supra note I, s. 14(1), provides that "[1]he Minister may establish water guidelines" but it seems clear from the manner in which that term is defined in s. 1(1)(hhh)(iii) of the $A c t$ that this $A d$ ministrative Guideline is a different creature.

In addition to the Cardston Transfer, supra note 85, sce also: (1) Decision Statement: Transfer or Water Allocation between BGA Sales LId. and Gouw Quality Onions Lid, 8 Seplember 2004 |BGAlGouw Transfer]: (2) Decision Statement: Transfer of Water Allocation hetween the Uniled Irrigalion District and the South East Alberta (SEA) Co-op Ltd, 14 May 2004 [UIDSSEA Trans/er]: (3) Decision Statement: Transfer of Water Allocation between the United Irrigation District und the Villages of Hillspring and Glenwood, 27 February 2003 [UIDIGlenwood Transler]. Nicol, simpra note 25, provides additional commentary on each of these decisions.

The form is posted online: Alberta Environment <www3.gov.ab.ca/env/waler/legislation//orms/transfer application.pdis.

Alternatively, the transfer may be authorized by order in council: s. 81(7)(a)(ii).

Sinee this is a condition precedent, it follows that if an applicant cannot satisfy the Director that it is in compliance, then the Director has no jurisdiction to consider the application further. 
An example of the first is Phase One of the South Saskatchewan River Basin Water Management Plan, which had as one of its key goals to put in place a system for approving transfers of water allocations. Accordingly, the Plan fulfills the requisite statutory condition precedent. It also offers some additional guidance for the Director in considering transfer applications."

The Act does not define the term "in good standing." Both the SSRB WMP and the Administrative Guideline offer some additional guidance as to how the term might be interpreted. Consistent with the recognition that "good standing" is a condition precedent to any consideration of an application, the Administrative Guideline notes that there must be a determination of good standing before consideration of the application. The Administrative Guideline refers to this as a certification process and it is certainly daunting for a potential applicant. The Guideline has a list of standard questions including such obvious questions as: Is there a licence? Does the licence reflect the current ownership of the appurtenant land? Are there any enforcement or even administrative appeal matters affecting the licence? It goes on to provide that staff must also carefully examine the actual wording of the licence terms and conditions to unsure compliance and may conduct a field inspection. Evidence of overuse or evidence of diversion at times other than those authorized by the terms of the licence may lead the Department to initiate compliance measures." While the "good standing" procedure may be daunting from an applicant's perspective it could, if rigorously applied, serve the important public interest purpose of limiting the extent to which the transfer of sleeper and dozer licences may contribute to increased withdrawals of water.

SSRB WMP Phase One, supra note 4 at 10, lists both factors and criteria for approval. Some of these factors are referred, to below. In addition, other parts of the Plan suggest other relevant considerations. For example (at 4) the document suggests that transfers within the same sub-basin are more likely to be approved than transfers between sub-balsins since the latter are "expected to be problematic because the allocation could be senior to existing allocations in the sub-basin [of' the Iransferee] ... and thus possibly have an adverse effect on them." The Plan also suggests on the same page that since the Act does not favour one type of water use over another in issuing a licence, the same use-blind approach will apply to transfers. This last stalement is somewhat problematic. First, it is likely inconsistent with the $E A B$ decision in Capstonte (Monmain View Regional Watcr Services Commission v. Director. Central Region. Regional Services. Alherta Environment re: Capstone Energv (26 April 2004), Appeal Nos. 03-116 and 03-118-121-R (Alta. Environmental App. Bd.))(discussed in Bankes, suypra note 45 al 139) but it also conflicts with other guidance offered by the Plan. For example. different uses provide different retum flows and the Plan certisinly acknowledges that the Director should have regard to effects of the proposal on the aquatic environment. The Draft Phase Two Plan (at 13), confirms this list of factors and criteria but also adds an additional factor that the Director must consider ("Existing trealy rights and other interests of First Nations in Alberta"). The most important recent authority on the Crown's duty to consult in the conlext of the numbered treaties of the prairie provinces is Mikisew Cree First Nation v. Canada (Minister of Cinculiem //eritage), 2005 SCC 69, [2005] 3 S.C.R. 388. The SSRB Approved Plan, supra note 4, contains some additional changes.

43 The stringency of these measures may deter potential translerors unwilling to undergo this scrutiny from entering the market. They may simply prefer to "let sleeping dogs lie" unless they are sure they are in compliance. "Good standing" was a significant issue in one of the early translers under the Act (BGAlGuow Transfer, stupra note 88). In her review of this case, Nicol, stura note 25 at 133-35, notes that the vendor of the licence had not used the right for so long as he had owned the land. The Department apparently required the vendor to prove that he could operate an irrigation system on the land. This required him to estimate the cost of equipment and to obtain a letter of eredit from the bank. 


\section{b. Public Review by the Director}

Section $81(6)$ of the $A c t$ stipulates that the Director "must conduct a public review of a proposed transfer" but it has little to say about the content of that review other than to indicate that it must be "in a form and manner that the Director considers appropriate." The subjective language of this provision no doubt affords the Director considerable latitude in deciding how to structure the public review, but it is still the Director that must conduct the review." This is prima facie a non-delegable duty ${ }^{95}$ and not the sort of duty that could be delegated to a private party. ${ }^{96}$ That said, both the Administrative Guideline and the current practice of the Department suggest that the Director has seen nothing improper in discharging this obligation by having the applicant provide public notice of the application, ${ }^{97}$ advertise, host and pay for an open house to receive public input, and provide "a public summary consultation report" to the Department. ${ }^{98}$

The section uses the active voice and not the passive voice. It does not, for example, state that "the Director must ensure that an appropriale public review of the proposal is conducted"; it actually requires the Director to conduct the review. If the Director does conduct the public review, whether orally or in writing or through a notice and comment procedure in addition to that prescribed by s. 108 , then it seems clear that a reviewing court would be highly deferential to the Director's assessment of the appropriateness of that review. The standard considerations in assessing the standard of review are: (1) the existence and nature of a privative clause; (2) the expertise of the tribunal; (3) the purpose of the Act as a whole and the purpose of the particular provision; and (4) the nature of the problem - a question of law or fact: Pushpanathan v. Canada (Minister of Citizenship and Immigration), [1998] I S.C.R. 982 [Pushpanathan].

9. I argue that the duty is non-delegable for two reasons (Vine v. National Dock Labour Bourd. [1957] A.C. 488 (H.L.), which held that in deciding whether a "person" has power to delegate, one has to consider the nature of the duly and the character of the person). First, the stutute identities the director as the person who must conduct the hearing. If the statute had identified the Minister, there might be an argument of an implied authority to delegate, at least to another official within the Minister's Department (Baker v. Canada (Minister of Citizenship and Immigration), [1999] 2 S.C.R. 817). Second, the particular function is that of conducting a public review. This is an important public policy function designed to elicit and weigh the expression of different, and perhaps contrary views, in fulfilment of the objectives of the Act. Again, this might possibly be delegated to a hearing oflicer(see Local Government Board v. Arlidge, [1915] A.C. 120 (H.L.)) but the $A c t$ does not contemplate privatization of this function. Consultation by the transferor is qualitatively different as is (sec infra. Part III.F.2) a referendum designed to assess whether a transfer is in the best interests of an irrigation district.

The applicable standard of review would depend on how the issue was characterized. There is at least some basis for characterizing the issuc as a pure question of law: either. the proper interpretation of the term "must conduct a public review" or, and more likely, whether the discharge of that duty might be delegated to an ID.

The Director's decisions rely to some extent on the s. 108 notice that an applicant for a transfier is required to provide "in accordance with the regulations." While the notice is clearly an important part of any public review, it cannot itself satisfy the requirement of $s$. $108(6)$ for otherwise that subsection would be deprived of content.

See Administrative Guideline, supra note 82 at 15-16, and for examples of practice consult the following: (1) Cardston Transfer, supra note 85, where para. 3 of the summary of decision notes that "a combination of notice under Section 108 and a public review meeting held by the lown ... have been accepled as appropriate public review for the transfer"; (2) UIDLSEA Transfer, supra note 88 at para. 4 , states that "a combination of notice under Section 108 a public meeting held by the [II)] and a District Plebiscile ... which included an affirmative referendum vole for the transfer to occur ... have been accepted as appropriate public review for the Iransfer." The reference to the relierendum is a reference to the referendum required by s. 11 (1)(a) of the IDA, supra note 2, where the IDA is a proposed Iransferee of a licence. This latter secms especially problematic sinee the Water Act contemplates that it is the Director who must conduct the public review. While an ID perhaps serves both public and private functions, it is clear from a comparison of the purposes sections of the statutes that they have quite different concerns and objectives. See Nigel Bankes \& Arlene Kwasniak, "The St. Mary's Irrigation District Licence Amendinent Decision: Irrigation Districts as a Law unto Themselves" (2006) 


\section{c. Approval or Denial, Terms and Conditions}

Section 82(5) of the $A c t$ lists the factors that the Director may or must take into account in considering an application. ${ }^{99}$ The only factors that the Director musf take into account are "the matters and factors" stipulated in an applicable approved water management plan. ${ }^{100} \mathrm{To}$ date there is only one such plan, the South Saskatchewan Plan, but the content of that plan suggests that there is potential for considerable overlap between the permissive factors listed in the $\mathrm{ACt}$ and the lactors that adoption of the Plan may make mandatory.

Closer examination of the SSRB WMP confirms that it actually does two things: (1) it lists a set of factors that by force of listing become mandatory; and (2) it then stipulates criteria for approval, thereby purporting to substantively bind the Director's excrcise of discretion. While some of these factors and criteria do little more than repeat the relevant statutory language (e.g., factor) "assessment of effects on the aquatic environment" and (criteria) "no significant effect," 101 others go beyond. For example, the following factors and criteria are incremental to the requirements of the $A c t$ : (1) (factor), water quality, (criteria) no significant adverse effect on public health and safety or assimilative capacity; (2) (factor) surface/groundwater linkages, (criteria) no significant adverse effect on groundwater quantity or quality; and (3) (factor) apportionment agreement, (criteria) the terms of the agreement to be respected.

My reading of the water planning section of the $A c t$ (s. 11) combined with s. 82 suggests that inclusion of a factor within the Plan suffices to make it a mandatory consideration for the Director. It is less clear that the Plan's listing of "criteria for approval" is equally binding on the Director.

While all of the other factors listed in s. 82(5) of the $A c t$ are, on the face of it, expressed to be permissive, i.e., the Director "may consider" (that is if a water management plan has not converted them into being mandatory), a more contextual reading of the entire section suggests that at least some of these additional "permissive" factors must in any event be mandatory. The permissive list includes such factors as: the existing, potential, or cumulative effects on the aquatic environment, any applicable water conservation objective, and other users that may result from the transfer; the suitability of the transferee's land for irrigation (if that is the purpose of the transfer); the amount of water the licensec has historically diverted; and any other matters the Director considers to be relevant. But this permissive list

16 J. Envtl. L. \& Prac. 1.

The Director's power to approve or deny a transfer application is expressed to be subject not only to the accompanying ss. $81-83$ but also to s. 34. Section 34 of the Act accords the Minister the power to order the Director not to approve an application for a transfer where the Minister reaches the conclusion that the transfer is not in the public interest. The Minister is required to provide the applicant with notice of the proposed order (s. 34(4)) in aceordance with the regulations. This is an extraordinary power, it bears emphasizing that it does not authorize the Minister to grant the application if the Director is minded to deny it.

Supra note I, s. II(3)(a)(iv)(B), specifies that an approved WMP must include a statement of "the matters or factors that must be considered in deciding whether ... (1) approve a transfer of an allocation of water under a licence." 
has to be read in the context of s. $82(3)$, which provides that the Director may only approve a transfer if: ${ }^{102}$

- The transfer will not, in the opinion of the Director, impair the rights of a third party ${ }^{103}$ or, if it will, that the third party has agreed in writing to the transfer.

- The transfer will not, in the opinion of the Director, "cause a significant adverse effect on the aquatic environment."

The effect of these provisions must be to move elements of the permissive list of relevant considerations to the mandatory list when ss. 82(3) and (5) are read together.

In sum, while s. 82 appears to distinguish between a short list of mandatory factors and a much longer list of permissive factors that the Director must take into account when making a decision, this distinction will likely not prove to be very important for at least two reasons. First, the content of a water management plan may serve to convert permissive factors to mandatory factors and, second, when read as a whole the section will require the Director to take account of apparently permissive factors if the Director is to fulfill all of his or her obligations under the section.

The no-impairment, no-adverse effect tests impose a very high threshold that must be met before a transfer can be approved. Certainly it is much more rigorous and less malleable than a general public interest test. However, experience in the United States suggests that it may be important to consider at least two additional issues in the application of the noimpairment, no-adverse effect tests: (1) the distinction between licensed quantities, quantities actually diverted, and quantities actually consumed (i.e., actual diverted volumes minus return flows); and (2) the question of who has the burden of proof..$^{10 t}$

If the Director grants the application, he or she will issue a new licence to the transferee with the same priority as that of the transferor and specifying the appurtenance of the new licence (ss. 82(1)(a) and (7)). ${ }^{105}$ Since the licence is a new licence under the $A c t$, the

There is an additional pro forma requirement to the elfect that the application not result in a greater volume of walce being transferred than the original licence authorized.

(II) Sitpranole I, s. 82(3)(b) lists houschold users, Iraditional agricultural users, and other licensees: we shall use the generie term "third party" to describe this basket of users. See generally Gould, stypra note 16, and the text to sumra note 37 for discussion of third-party effects.

As to the first point, Tarlock, supra note 18 at 46 , notes that one of the implications of a no-harm rule is that "the senior right holder can only transfer the amount of water that it consumed rather than the water it originally diverted." Sax goes further (supra note 20 ), emphasizing that since water is a community resource we need to ensure that we compensale communities who suffer losses from transfers and not just junior rights holders. As to the sceond point. Gould, sutpra nole 16 at 35 et seq., suggests that in U.S. jurisdictions the parties to the transfer will have the burden of prowf. However, he noles considerable diversity as to the standard of prow. Wyoming seems the most stringent, requiring the transfer proponent to prove lack of injury by clear and convincing evidenec, while the Utah courts merely require the proponent to make a general showing of no injury and then rebut specitic elaims of injury. The later seems an appropriale approach given the difficulties of proving a negative. The Department's Administrative Guideline, supra note 82, do not deal diretely with questions of onus and standard: certainly they do not require applicant to provide a no-harm assessment. answer must be "yes": the Director must be able to impose conditions to ensure that the sransfer will not have a significant adverse effect on other users or the aqualic environment. The Director will also need 
transferee's entitlement is subject to s. $51(5)$, which requires that any new licence must stipulate an expiry date. This is certainly the position of the Department. ${ }^{106}$ It is the transferee that has the power to apply for licence renewal under s. 59. The transferor has no such right. Thus, a transferor of a pre-1999 licence that was issued without a specified term cannot transfer a perpetual entitlement to a transferee but can, at most, transfer the right to apply for a renewal. ${ }^{107}$

The Director must also amend the transferor's licence. If the transferor is transferring its entire entitlement (both in terms of volume and duration) the transferor has nothing left and it must follow that the transferor's licence should be cancelled (s. 82(6)(b)). Where the transferor will retain an interest (either a reversionary interest, or a part of the original allocation), the Director may amend the licence both to give effect to the transfer but also to make any further amendments so long as "they are within the Director's powers to amend under section 54."'110

This latter statement is a reference to a lengthy section of the Act dealing with amendments to licences. The section is divided into two parts. The first part deals with those amendments that the Dinector is able to make of his or her own initiative. The second part deals with those amendments that the Director may make on the application (and therefore with the consent) of the licensee. ${ }^{104}$ Among the more important powers that the Director has to amend on his or her own initiative are the omnibus power to amend "to give effect to a

to impose new terms and conditions relevant to the new point of diversion. Sec, for example, the new condition inserted in the Town of Cardston's licence on a transfer (Cardston Transfer, stupra note 85). The new condition was designed to ensure that the "diversion from the St. Mary location will not interfere with use between the new point of diversion and the confluence of l.ce Creck and the St. Mary River." It is less clear that the Director can impose new terms and conditions (e.g., a minimum flow" requirement in order to better the health of the aquatic environment). This is something that might only be done as part of a conservation holdback; (2) A related point is that while the Act clearly grandparents "priority." it does not suggest that the new licence has entirely the same status as the original licence. This may be important in the context of the grandparenting provision of s. 18, i.e., the new licence may not be a deemed licence for the purposes of 5.18.

See Administrative' Guideline, supra nole 82 at 9: "The licence will be issued with an expiry date as per Section 12 of the Water (Ministerial) Regulations."

107 It may be possible 10 make a contrary argument bused on s. 82(6)(b), which uses the word "permanent." But that may simply refer to the entirety of a term licence rather than serving as the authority to issue a new licence without term to a transferec. The partics should be able to avoid the result of converting a permanent licence into a renewable licence by having the transferor execute a limiled term transfer (leaving the transferor with the reversion) but this is hardly satisfactory lrom the perspective of the transferec.

tos Surpa note 1, s. 82(6)(a)(ii). SSRB WMP Phase One, supra note 4, purports to limit this authority further as follows (at 10): (factor) current conditions in the transferee's licence, (criteria) "[i]n the case of a transfer of part of an allocation, there will be no adjustments to the current conditions on the part of the allocation that is not being transferred. unless necessary to give effect to the transfer." The Draft Phase Two Plan reiterated this point. The SSRB Approved Plan, stipra note 4, does not refer lo this point.

(w) Presumably this might include, as in $5.54(1)(a)$. "at the initialive of the Director but with the consent of the licensec." This may be an important clarilication insofar as it suggests the possibility of sone negoliation as part of the process of approving a transfer. The Director may he prepared to say something like. "I ll approve the trans fer but as part of the deal I need you to agree to this amendment." The UIDISEA Transfer, supra note 88, offers some support for this. In that case, the decision report (at para. 13) notes that the Director decided not to require a conservation holdback partly because there was no instream flow issue in the Belly River during the 15 days during which diversion might occur (the proposal was for a diversion to store water in a reservoir for subsequent use) but also because "the licensec agreed to a $33 \mathrm{cfs}$ minimum flow being attached to their license." 
transfer of an allocation"; "I" and the power to amend "if there is a term or condition of the licence allowing the amendment";"' and the power to amend, as in s. 54(1)(a)(v), "if, in the Director's opinion, an adverse effect on human health or public safety occurred, occurs or may occur that was not reasonably foreseeable at the time the licence was issued." This power is distinct from the Director's power to amend the licence to respond to unforeseeable adverse effects of the aquatic environment. This latter power is subject to a potential liability to pay compensation. ${ }^{112}$

The Director's power to amend on the application of the licensee includes such things as increasing or decreasing the rate of diversion, adding terms and conditions to the licence and changing the point of diversion. Both sets of powers (the power to amend on own initiative and on the application of the licensee) are subject to two general provisos: (1) there shall be no increase in the volume of water subject to diversion; and (2) an assessment by the Director that the amendment will not have an adverse effect on the interests of third parties. ${ }^{113}$

It is perhaps worth emphasizing that neither branch of s. 54 explicitly confers on the Director the power 10 amend the purposes clause of a licence. Neither do the transfer provisions of the $A C l$ expressly address the scenario in which the transferee wishes to use the water for a purpose other than a purpose included in the original licence. In practice, the Director does not seem to be deterred by the silence of the $\mathrm{Act}$ and has approved amendments to uses both as part of a s. 54 application ${ }^{14}$ and as part of a s. 81 transfer application. ${ }^{15}$ The Act might usefully be amended to clarify this point. ${ }^{116}$

110 Supra note 1, s. 54 (1)(a)(ii). This suggests that a transfereeltransferor need only make one application (i.e., for the approval of the Iransfer). There is no need for an additional application to amend the licence.

III Jbid., s. $54(1)(a)(i x)$. For discussion of some far-reaching clauses designed to allow adjustments in the future, see Alastair R. Lucas, Security of Tille in Canadian Woter Rights (Calgary. Alta.: Canadian Institute of Resources Law.1990) esp. c.4.

11: Water Act. ibid., s. 54(2), and referring both to the regulations and to 5.158 dealing with compensation.

113 Presumably, in the case of amendments that result from transfers, this gencral limitation on the power must be subject to agreements in writing "authorizing" the amendment (s. 82(3)(b)). The contrary argument might be that since an amendment of purposes might alfect other licensees (e.g., reduced return flows) one might expect it to be addressed expressly.

11 Sec, for example, a sucesssful application by the St. Mary River Irrigation District, which was the subject of an appeal: Bankes \& Kwasniak, supra note 98.

11s SeeUIDISEA Transfer, supra nole 88. The transferee's proposed use was for a community water supply. It is unclear from the Decision Stalement if this was already an authorized use lor the UID or whether this represented a change of use lirom irrigation to community water supply.

116 The argument of implicit authorization to amend the authorized purposes of the diversion would be based on the opening language of $s .54(1)(b)$, which provides that the Director may amend a licence "on application by the licensec. inchading but not limited to an amendment" [cmphasis added]. As part of the consultations that led to the Drath Phase Two SSRB WMP, stpra note 4, there was some discussion within the Basin Advisory Committee (BAC) as to whether or not the. South Saskaschen'an Basin Water Allocation Regulation. Alta. Reg. 307// 991, might serve to require transfiers lor irrigation purposes to be rejected when the limits prescribed in that regulation were reached. Scetion 4 of that regulation stipulates that the amount allocated lor irrigation purposes under existing and future licences "or other authorizations" must not exceed the amount of water required to irrigate specilied maximum acreages for each ID. Section 5 is a similar provision for areas, including Indian Reserve projects, falling outside the IDs. At least some members of the BAC took the view that this was an artificial constraint and that transfers should be driven by the market. The Draft Phase Two report contained no specific commentary on this other than to recommend (at 10) that the Regulation be repealed. The SSRB Approved Plan, supra note 4 at 10. reaflirms this recommendation. 
One of the implications of the amendment power from the perspective of the participants is that it further exposes the transaction to the exercise of statutory discretionary powers and therefore creates additional uncertainty. From a more general public interest perspective, this may create an additional opportunity to protect aquatic environment values.

\section{d. The Water Conservation Holdback}

The final element of the transfer process is the application of the much touted "conservation holdback" provision of the Act, s. 83. Under this section, "the Director may withhold up to $10 \%$ of an allocation of water under a licence that is being transferred"117? where he or she "is of the opinion that withholding water is in the public interest to protect the aquatic environment or to implement a water conservation objective" 18 at least where use of this power has been authorized under an applicable approved water management plan or otherwise approved by order in council. The South Saskatchewan Plan provides this basic authorization."'"

The $A C t$ affords the Director ${ }^{130}$ three means of implementing a holdback decision. The Director may: (1) simply leave the water in the waterbody; (2) "reserve" the water under s. 35 of the $A c l$; or (3) issue a licence ${ }^{121}$ to the Government for the holdback amount under s. $51(2)$ of the $A C t$ with the terms and conditions ${ }^{122}$ and priority of the original licence. What are the implications of each of these alternatives?

Supra note 1, s. 83(1). There would appear to be some ambiguity about the framing of this provision: is it 10 percent of the amount of water (the allocation) that is propesed for transfer, or is it 10 pereent of the full licensed amount no matter how much is being Iransferred? To the extent that there is an ambiguity here, and to the extent that a holdback represents an interlerence with vested rights, one would expect a court to opt for the more restrictive interpretation ol the Director's powers notwithstanding judicial recognition of the importance of environmental values (see David R. Boyd, Unnatural Law: Rethinking Canadian Emironmental Lav and Policy (Vancouver: University of British Columbia Press, 2003) at 221-23). On the protection of vested rights see Moryuurd Properties Lid. v. City of Winnipeg, [1983] 2 S.C.R. 493 at 509. Note that s. 83(4) explicilly addresses the application of the holdback in the scenario where the licensee retains a reversionary interest. In this situation the Ac/ specilies that the holdback remains with government and does not revert to the licensec. The Department's interpretation (ste Administrative Guideline, supro note 82 at 9 ) is that the holdback is calculated on the amount that is the subject of the translier.

Water Act, ibid., s, 83(1). The subjective language of this section suggests a reviewing court would owe a high degree of deference to the Director's decision and any subsequent decision of the $E \wedge B$ on appeal: see Pushpanathon, suppra note 94 and, in the context of the EAB, see the discussion in Bankes, stipra note 45.

SSRB WMP Phase One, supra note 4 at I1. The Plan also offered the Director some additional guidance, suggesting that the Dircetor should ordinarily exercise the holdback given "the broad coneerns expressed hy the public that there may be insufficient flows remaining in the rivers of the SSRB." The Plan went on to make special referenec to waterbodies subjeet to moratoria. The Plan also recommended that if it appeared, once water conservation objectives had been established, that more water had been withheld than was required "then it is recommended that Director return the excess to the licence holders, in proportion lo the origimal witlholdings," It is lairly clear that the Act dow's not provide for such a "rebate."

The section actually adopts the passive voice, perhaps in recognition of the fact that at least one of the options refers to a statulory power that is exercisable by the Minister (the s. 35 reservation power). The actual language of the section is the negative and rather curious formulation to the effect that, under s. 51(2), the Director may not issue a licenec to any person other than Govemment.

12. The suggestion that the new licence must reflect the same conditions as the original licence is subject to some qualification. See lext to supra notes $102 \mathrm{ef}$ seq. 
The first option would seem to do the least for the values that the conservation holdback is trying to protect since the effect of leaving water in the stream will be to allow other licensed users and appropriators with a low priority (and who might otherwise therefore be cut off) to divert that water. Indeed, and notwithstanding the express statutory authorization of this option, one would think that any decision by a Director to use option one could readily be characterized as patently unreasonable ${ }^{123}$ except in the most exceptional circumstances. ${ }^{124}$

The second option incorporates by reference a long-standing provision of the $A c t^{125}$ authorizing the Minister to make a "reservation." Section 35(1) of the $\mathrm{ACt}$ authorizes the Minister to reserve water that is not allocated under either a licence or registration "in order to determine how the water should be used" or "for any other purpose." Without exploring all of the details of this highly discretionary section, it seems safe to say that the reservation option is a "holding option" that allows the Minister to defer making a decision to issue a licence for providing or maintaining a minimum flow under $s .51$ to implement a water conservation objective. This option has one significant drawback from the perspective of conservation values. Where water held under a reservation is subsequently allocated, the priority of that allocation can be no earlier than the date of the reservation (not the date of the original licence from which the conservation holdback was taken). ${ }^{126}$

The third option involves the issuance of a licence to government under s. 51(2) of the $\mathrm{ACt}$ to provide for a diversion of water or "providing or maintaining a rate of flow of water or water level requirements" in order to implement a water conservation objective. In this case the licence must be issued "in accordance with the priority number and terms and conditions of the licence from which the water was withheld."'27

In the four transfers that I have reviewed, the Director has exercised the discretion to assert the full 10 percent holdback in two cases. ${ }^{12 x}$ In each of those cases, the decision document stipulates that the withheld water will be applied to a licence for a water conservation objective applied for by the Government of Alberta. The Director offered a variety of reasons for not exercising the holdback authority in the other two cases. ${ }^{129}$

This is, of course, a relierence to the stanclard of review that a court would likely apply to a decision of the Director (or more likely to a decision of the EAB) - see supra note 94.

Such as where there is no other licensed appropriator on the waterbody.

See Water Resources Act, supra note 10, s. 12.

Supra note I, s. 35(2)(b). In fact, when one looks at this section in conjunction with $\mathrm{s.} 51$ (2) (issuance of a licence) and s. 29(2)(c) (the priority section) there is at least some ground for suggesting that in this case the priority can be no carlier than the date of the completed application for the licence.

Ibid., s. 83(3)(c). The reference to the terms and conditions of the original licence seems more than a little curious. What if they are completely incompatible with the conservation objective the new licence is intended to achieve?

Cardston Transfer, supra note 85 and UIDIGlenwood Transfer, supra note 88.

(A) BGA/Gouw Transficr, supra nole 88. ofiers four reasons: (1) no WCO objective established for the Oldman; (2) instream objective currently met by the Oldman Dam and reservoir; (3) the new licence will be subject to these instream objectives: and (4) 41 percent of the original licence was being cancelled (the decision document does not explain the reason for this); (B) UIDISEA Transfer, stupra note 88; see supra note 109. The Dratl SSRB WMP Phase Two repor, stupro note 4 at 11 , provided some additional guidance insofar as it suggested that a holdback may not be justifiable where the point of diversion is being moved a considerable distance downstream since "the entire allocation is then contributing to increased hows over a greater distance." The SSRB Approved Plan, supra nole 4 at 12, offers the more general recommendation that the Director should withhold the full 10 percent "unless there is a 


\section{e. Review of the Director's Decision}

As we have seen, the $s 3$ assignment procedure is characterized by a self-assessment of the effects of an assignment. We have also noted that, even where the Director subsequently intervenes and issues "directions" (or for that matter, and perhaps more importantly, decides not to issue directions), there is no opportunity for review by the EAB. By contrast, the transfer procedure provides not only an opportunity for a prior public review but, in addition, the Director's ultimate decision can be appealed to the EAB in accordance with Part 9 of the Water Act by a person who has submitted a statement of concern in relation to the original application. ${ }^{130}$ An appeal might relate to a decision to approve or deny a transfer, to the terms and conditions imposed as part of approving a transfer, or to a decision to exercise or not exercise the conservation holdlback.

\section{RESTRICTIONS ON TRANSFERS BY IRRIGATION DISTRICTS}

It goes without saying that the decision of the transferor to transfer its assignment will need to comply with any internal restrictions that may apply to that transferor. While this is not the place to canvass the application of business corporations legislation to such dispositions where a licence happens to be held by a corporation, it is important to refer to s. 11 of the Irrigation Districts Act which pertains to transfers of licences held by irrigation districts (IDs). As we haye noted, IDs are responsible for over 70 percent of licensed water volumes in the South Saskatchewan Basin ${ }^{131}$ so it is important to assess any constraints that the $I D A$ may impose on the capacity of an ID to transfer its most significant asset.

As originally enacted in $1999,,^{132} \mathrm{~s} .11$ imposed signiticant procedural conditions that an ID would need to meet before it could engage in a transfer of an allocation of water under a water licence. ${ }^{133}$ An amendment to the $I D A$ in $2002^{134}$ relaxed these provisions to some extent but they remain relatively stringent.

The original scheme provided that an ID could not apply to transfer a licence unless the board of the ID had first held a meeting with the public and a majority of those voting in a plebiscite favoured the application. The new 2002 provisions preserve the basic elements of this scheme but also allow the Minister to waive the requirement for a plebiscite if the board establishes to the Minister's satisfaction that: ${ }^{135}$

compelling reasons to withhold less."

130 Supra nole 1, s. 115, and sec more generally Bankes, supra note 45.

131 Alberta Environment, supra note 14.

132 S.A. 1999 , c. 1-11.7, s. 11.

133 These constraints onily apply to an ID as a transferor not as a potential transferee. They also do not apply to assignments under s. 33 of the Water $A c t$, but it does not follow from this that an ID could enter into an agreement to assign water. See discussion of this point in Part IV.E, infra. 
(a) the proposed transfer will have no significant effect on the risk of water shortage to the irrigators of the region, or

(b) the proposed transfer is in the public interest. ${ }^{136}$

But whether the Minister waives the requirement for a plebiscite or not, the ID is still required to make certain information publicly available. This includes information about the total volume of water available to the ID under all of its licences, the volumes required for irrigation and non-irrigation purposes, and the level of risk of a water shortage. While the regulations require the ID to identify the potential transferee, they do not require the ID to reveal the proposed consideration for the transfer. ${ }^{137}$

\section{THE DURATION OF TRANSFERS}

We have already seen that the $A c t$ is far from clear on the question of an agreement to assign under s. 33. All that we know of such agreements is that they are supposed to be "temporary." The position is much clearer with respect to transfers since, as we have already seen, $s .82(2)$ provides that a transfer may be made for all or part of an allocation of water under a licence and "either permanently or for a specified period of time." Where the assignment is for a specified period, s. 82(8) makes it plain that on the expiry of this period the allocation of water reverts back to the original licence and the transferee's expired licence "is void."

\section{OTHER RESTRICTIONS ON TRANSFERS}

In principle there is nothing to prevent any person qualifying as a transferee, although some transferees may face particular qualifying hurdles. For example, if the proposed transferee wishes to use the water for irrigation purposes, the transferee will need to establish (s. 82(5)(c)) that the land to which the new licence will be appurtenant is suitable for irrigated agriculture.

More important perhaps is the effect of s. 51(2) of the Act. This subsection provides that "no other person" other than the Government may hold a licence for "providing or maintaining a rate of flow of water or water level requirements" at least where the purpose is to implement a water conservation objective. Consequently, while a conservation organization may hold a licence to permit a diversion for a wetland and, therefore, take a transfer of a licence for that purpose, that same organization cannot hold a licence or take a transfer of a licence for the purpose of leaving water in the river to meet instream flows. ${ }^{138}$

13* The Draft SSRB WMP Phase Two report, supra note 4 at 15 , stated that, as a result of public input, the Department would "put fonvard a proposal to amend the Water $A c t$ to permit privatc parties to hold such licences, when obtained under the transfer provisions of the Water Act." The SSRB Approved Plan, supra note 4 at 17 . confirms this recommendation. 
Finally, just as with respect to assignments, there is a "no double dipping" rule in relation to transfers. ${ }^{139}$

\section{F. Conclusions}

The Water Act provides two distinct methods by which a person may acquire a water entitlement from an existing user, the s. 33 assignment and the s. 81 transfer. Closer analysis, however, suggests that the $\mathrm{s} .33$ assignment may only be used in very limited circumstances. In particular we have seen that: (1) a proposed assignee must already hold a water entitlement; (2) an assignment cannot provide an entitlement to an incremental supply of water to an assignee, but can only improve the priority of the assignee's entitlement; and (3) since the $A c t$ requires that assignments must be temporary, it is unlikely that an assignment could be used as a contingent contract to afford long-term security to a low priority user.

The s. 33 assignment procedure does not require prior approval from the Director or other Departmental officials. While there is some limited opportunity for the Director to intervene post hoc, we have suggested that these procedures will be difficult to use. While this may compromise public interest values in the water resource, the degree to which this will be a concern may be mitigated by the inherent limitations surrounding the use of the s. 33 assignment procedure. We should also acknowledge that the absence of the need for governmental approval has a positive aspect since it allows water users to develop quick responses to seasonal or other crises. From this perspective, the 2001 "share the shortage agreement" was a useful and welcome response to news of low snowpack conditions. ${ }^{130}$ In those circumstances, junior licensees could not have protected their position by acquiring licence transfers that year for there is little chance that the regulatory process for licence transfers could (or should) move that quickly even assuming that buyers and sellers could be matched.

The s. 81 transfer can be used to fulfill a broader variety of long-term needs of potential transferees (and transferors), but is also subject to a much more intense level of regulatory scrutiny. From one perspective, this level of scrutiny is to be welcomed as it should serve to ensure, so far as regulatory oversight can, that a transfer causes no incremental negative impacts on important public values including the aquatic environment and the rights of existing users. On the other hand, potential parties to a transfer may see the process as unduly costly and threatening (c.g., the certification of "good standing." the conservation holdback) and unduly onerous. ${ }^{1+1}$ This may make potential transferors reluctant to enter the market and may cause potential transferees to explore other possibilities for securing rights in an environment (e.g., an irrigation district) that is subject to a lower level of regulatory security.

Supra note I, s. 82(3)(a).

See discussion, supra at Part III.D.4.

Interests in other publicly-owned resources are generally assignable cither without any need for prior approval or with only limited scrutiny, and the general trend in recent years has been to reduce the level of scrutiny. For an example of a very liberal regime sec Alberta's. Mines and Mfinerals Act, R.S.A. 2000. c. M-17. Part 6. That said, assignment of private rights in publicly-owned resources continues to attract scrutiny in some provinces and in relation to some resouree sectors. Perhaps the most notahle example is British Columbia's forest sector, see Forest ACt, R.S.B.C. 1996, c. 157, Part 4 (but even these provisions are more restrained than they used to be). 


\section{G. AN EXCURSUS: SPECIAL FORMS OF "TRANSFERS"}

This section of the article deals with two special restrictions that the $A C t$ imposes on applications for licences that, if granted, would: (1) authorize the "transfer of water" from one water basin to another; or (2) from the province to an area outside Canada. ${ }^{142}$ It should be apparent that the word "transfer" is being used in a very different way in these two sections of the $A C t$ than it is being used either in ss. $81-83$ of the $A C t$ or in this article. In each of these special cases, the $A c t$ focuses not on the transfer of an existing entitlement from one user to another (i.e., a water allocation transfer) but on the issuance of a licence where the purpose of the licence is to authorize the use of water outside Canada (and this is the "transfer" that is contemplated - "to move or transport water" might have conveyed the meaning more clearly) or in a different (major) river basin: ${ }^{143}$

[A] liecnce shall not be issued for the purpose of transferring water from the Province outside Canada by any metans, unless the licence is specifically authorized by a special Act of the Legisluture. ${ }^{144}$

[ $A$ licence shall not be issued that authorizes the transfer of water between major river basins in the Provinec unless ... [same as s. 46]. ${ }^{\text {145 }}$

While the above discussion establishes that these sections are not directed at transfers or assignments as we have been using the terms, we still need to ask what might be the relevance of these provisions for our discussion.

We can make the point quite simply by positing that a proposed transfere ${ }^{146}$ is: (a) localed just across the border in Montana and seeking to obtain an Alberta water right on the Milk River; or (b) located in the same area but seeking to acquire a water right from a licensee on the St. Mary River. It is fairly clear that the transferee would not be able to avail itself of either the assignment or transfer provisions of the Act to give effect to either of these transactions. But the reasons differ in each case. In the case of an assignment, ss. 46 and 47 are simply not relevant since an assignment does not result in the issuance of a licence and ss. 46 and 47 speak only to licences. An assignment will fail in scenario (a) for the reason that the transferee is not eligible to take an assignment since it cannot hold an existing licence or registration since there could have been no land in Alberta to which the licence might have been appurtenant. An assignment will equally fail in the case of (b) since an inter-basin transfer or assignment of water cannot be effected "as a result of the natural flow

\footnotetext{
11: Supra note 1, ss. 46-47.

143 The major river basins (seven) are designated by s. 10 of the Woter (Ministerial) Regulation, supra nole 44.

it Shyra nole 1. s. 46(2). The section exempts "processed water" and "municipal water," cuch as defined in ibid., s. 1 (3)(c) and (e). Tlec exception for municipal walter is conlined (o) treulted water delivered under the terms of a decmed (grandparented) licenee as of the date the $A c$ c entered into foree.

14s Sipra note 1, s. 47. There have been at least two provincial statutes approving inter-basin trausfers: (I) North Red Deer Water Atthorization Act, S.A. 2002, c. N-3.5, authorizing a transfer from the South Suskutchewan Basin to the North Saskatchewan; and (2) Stenter Regional Water Authorizution Act, 2005, S.A. 2005, c. S- 19.5 (same).

Ith In this paragraph, I use the lerm "transleree" to embrace those persons taking under either a transfer or an assignment.
} 
or natural presence of the water" as required by the assignment provisions of the $A c t^{147} \mathrm{~A}$ Iransfer will fail in both scenarios (a) and (b) because in each case the applicant will be seeking the issuance of a new licence to give effect to the transfer and that must fall within the general prohibitory language of both ss. 46 and 47 , a "licence shall not be issued...." As we have already seen in the previous section, a licence issued as a result of an assignment is a "new" licence.

\title{
IV. RIGIITS AVAILABLE UNDER THE IRRIGATION DISTRICTS ACT
}

\section{A. INTRODUCTION}

There is considerable legal literature on the Water $\mathrm{Act}$ and the cognate statutes of other jurisdictions. ${ }^{148}$ There is a much more limited body of legal literature on irrigation legislation notwithstanding the dominant position of irrigation districts in Alberta and elsewhere. ${ }^{1+9} \mathrm{The}$ more general water resources literature, however, recognizes that "[w]ater organizations have a pervasive role in water resource allocation." 150 Marie Leigh Livingstone describes the economic rationale for such water organizations as follows:

\begin{abstract}
Water supplies are naturally concentrated into site-specific common pools or streans. Moreover, water is not perfectly divisible in tems of storage or transpontation. As a result. very significant economies of scale often exist in pumping and delivery. For instance, where diversion is necessary, individual irrigators are usually unable to transpon small amounts of water in isolation duc to costs of conveyance losses. Indivisibility means that water allocation and use must involve group decisions and actions. Therefore, water organizations become a natural management velhicle. ${ }^{\text {s! }}$
\end{abstract}

There are currently 13 Irrigation Districts in Alberta established or continued under the authority of the IDA. ${ }^{152}$ These IDs, all of which fall within the South Saskatchewan Basin, vary dramatically in size and wealth. The smallest district is the Ross Creek ID which has

Water Act, supra nole I, s. $33(1)($ d). Unless of course the delivery of water could be effected by means of the U.S. St. Mary Canal diverting waler into the Milk River. In addition lo Percy, supra notes 7 and 11 , see also (i.V. La Forest, Water Law in Caneda: The Atlomic Provinces (Otawa: Department of Regional Economic Expansion, 1973) and Lacas, supro note 111. While the legal literature may be limited there is a more extensive historieal litcrature, although even some of that literature bemoans the relative paucity of the coverage. Useful sources include: N.F. Dreisziger, "The Canadian-American Irrigation Frontier Revisited: The International Origins of Irrigation in Southetn Alberta, 1885-1909" [1975] Canadian Historical Sociely Historical Papers 211; E. Alyn Mitchner, William Pearce and Federal Covernmen Activity in Western Canada 1882-1904 (Ph.D. thesis, University of Alberta, 1971) [unpublished]; A.A. den Otter, "Adapting the Environment: Ranching, Irrigation and Dry Land Farming in Southern Albertu, 1880-1914" (1986) 6:3 Great Plains Quarlerly 171; Lawrence B. Les, "The Canadian-American Irrigation Frontier, 1884-1914" (1966) 40:4 Agricultural H listory 271: Renie Gross \& 1.ea Nicoll Kraunen. Tapping the Bow (Brooks, Alta.: Eastem Irrigation District Canuda, 1985). A purticularly useful and comprehensive contemporary assessment of the irrigation industry is Irrigation Water Management Study Committec, South Saskenchen'an River. Busin (SSRZ): Irrigation in the 2/s/ Century (Lethbridge, Alta.: Alberta Irrigation Projects Association, 2002), online: Alberta Agriculture, Food and Rural Development< <ww .agric.gov, ab.ca/Sdepartmeny depldoes.nsf/all/irr4421 \#Complele> [irrigation in the 2/st Century]. This is a five volume report with the first volume providing a 175 page summary.

Livingston, stupra note 35 at 25. 
a total irrigation area limit of 486 hectares, while the St. Mary and Eastern IDs have (respectively) area limits of 150,043 and 111,289 hectares. ${ }^{153}$

Section $6(1)$ of the $A c t$ provides that the purpose of each District is:

(a) to convey and deliver water through the irrigation works of the district in accordance with this $A c t$.

(b) to divert and use quantities of waler in accordance with the terms and conditions of its licence under the

Noler Acl.

(c) to construct. operate and maintain the irrigation works of the district. and

(d) to maintain and promote the economic viability of the district.

Paragraph (b) confirms the interrelationship between the Water Act, the IDA, the ID's Water Act licences and, notwithstanding the different purposes of the two statutes, case law in relation to the predecessor statute of the current $I D A$ suggests that the two statutes must be read in pari matcria. ${ }^{154}$ Indeed, it seems reasonable to think of the ID's water licences as being part of the ID's "constitution." 155 The recent decision of the Director to amend a licence held by the St. Mary's River Irrigation District (SMRID) illustrates this point. SMRID's licences initially provided that water diverted under the terms of the licence could only be used for irrigation purposes. SMRID sought to amend its licence so as to expand the range of purposes that it might be able to serve. I have criticized that decision elsewhere, ${ }^{156}$ but the key point here is the premise of the application, namely that absent that amendment SMRID would not have been able to avail itself of the flexibilities provided under the new $I D A$ to provide water to third parties for a range of municipal and industrial purposes. ${ }^{157}$

The IDA creates one main form of right to water, the right of "irrigation acres" and a number of subsidiary "rights" to water or to use the facilities of the ID. Two of these subsidiary forms of right are intended to create rights to water for irrigation purposes. These are the rights held under terminable agreements and annual agreements. Two other forms of rights allow the use of water for other purposes. These are the household purposes agreement and the rural water use agreement. The last two forms of agreements arguably deal with the use of ID facilities and do not create an entillement to water. These agreements are: the use of irrigation works agreement and the water conveyance agreement (WCA). However, there

13) Irrigation in the 2Ist Century, supra note 149, vol. 1 at 22.

is Friends of the Oldman River, supra note 13 at para. 12.

13s Several cases confirm this: Western frrigation District v. Damn (1996), 186 A.R. 57 (Prov. C1.) at para. 44 [Dann] ("W.I.D. clearly has to operate based on the wording of its licence which specifies the waler is to be used for irrigation and domestic purposes"); Friends of the Oldman River, ibid, esp. dicla at para. 22. Furthermore, the ID's rights and entitlements remain subject to the terms of the relevant water legislation (although in some cases see Bankes \& Kwasniak, supra note 98, with broader discretionary powers), see in this context. Trobst, stupra note 15 , where Virtue 3 . held that a tariff of "waler benefit" charges established by the ID under the then Irrigation $A C t$ and made applicable to land owners contiguous to the ID's Chestermere Lake Reservoir could only be validly levied if they complied with s. $54(2)$ of the I'ater Resources $A C t$, which required ministerial approval. That $A c t$ was amended shortly aflenvard to make ministerial approval unnecessary (sec the subsequent litigation in Denn, ibid. and Western Irrigation District v. Craddock (2000), 267 A.R. 297 (Q.B.)).

ish Bankes \& Kwasniak, ibid.

13. To emphasize the "constitutional" characterization above, the point is that while the IDA, as we shall sec. authorizes an ID to enter into a variety of agreements to fulfill different purposes, the ID can only enter into an agreement, say, to provide water for an agricultural processing plant, if its licence authorizes the use of water for commercial or industrial purposes rather than just irrigation purposes. 
is a view held by some that the WCA can be used not just to permit the use of ID facilities, but also to allow the $\mathrm{ID}$ to deliver a portion of its water entitlement to a user. ${ }^{15 x}$

In sum, there are potentially seven forms of agreement or entitlement that we need to examine:

- The right of irrigation acres;

- Terminable agreements;

- Annual agreements;

- Household purpose agreements;

- Rural water use agreements;

- Use of irrigation works agreements; and

- Water conveyance agreements

In what follows, we shall try to use the same analytical framework that we developed in the context of the Water Act. But we should also recall our earlier comments to the effect that any consideration of the entitlements of IDs and others under the $I D A$ must recognize that the analysis needs to proceed on at least three different levels. ${ }^{159} \mathrm{We}$ have already covered the first level of analysis in the preceding section (i.e., the ID as the holder of a water licence much like any other licensee). At the second stage we need to recognize that the various forms of entitlement available from an ID do themselves constitute reallocations of the ID's entitlement. At the third stage we must interrogate the alienability of those derivative entitlements.

\section{B. What DO THE VARIOUS ENTITI,EMENTS AUTHORIZF.? \\ 1. IRRIGATION ACRI:S}

The concept of "irrigation acres" lies at the heart of the IDA. The Act defines "irrigation acres" to mean "the acres in a parcel recorded on the assessment roll as "irrigation acres," while an "irrigator" is "an owner of a parcel with irrigation acres."1(5) More helpful and functional is s. 14, which tells us that, subject to the $I D A$ and the ID's by-laws, "an irrigator has the right to receive wvater for irrigation purposes for irrigation acres until the irrigation acres are removed from the assessment role in accordance with this Act." In addition to using water for irrigation purposes, an irrigator may also use water for houschold purposes (s. 19(4)). It is notable that the language used to describe the entitlement of the irrigator of

See discussion in Bankes \& Kwasniak, supra note 98.

Arguably there is a fourth level, which is the internal order of an ID. An ID may adopt by-laws relating to various matters ( $\sec 10$. . supra note 2, s. 177) and may also adopt policies. For example, SMRID) has adopted a policy on the translier of imigation acres and a policy on altemale parcel irrigation agreenents. Both policies are avnilable on the SMRID websilc, online: <www snurid.ab.ca/>. Similarly, the Lastem Imigation District (BID) has a set of Approved Practices and Guidelines Gencrning Water Defivery and Water Management Operations (2002), online: EID < wWw.eid.ab.ca/pdr/2002_ approved_practices, and_guidelines,pdi> [Approved Practices and Guidefines]. Given the variability in the IDs, it is elear that not all IDs will use all of the agreements referred to in the legislation and discussed herc. The purpose of the account that follows is simply to canvass the possibilities with the goal of specifying. as Freeman and Veeman suggest, supro note 11, the "property" interests that may be assignable. 
irrigation acres is much stronger than the language used to describe all other forms of entitlements under the $A c t$. Whereas an irrigator has a right ${ }^{161}$ to receive water, the standard statutory formulation used to describe all the other forms of entitlement is simply that the agreement "authorizes the delivery of water through the irrigation works of the district."162

\section{ANNUAL AND TERMINABLE AGREEMENTS}

Both the annual agreement ${ }^{163}$ and the terminable agreement ${ }^{1 / 4}$ authorize the use of water for irrigation purposes. The holder of such an agreement does not have the ancillary right to use a portion of this water for household purposes, but must instead enter into an additional household purposes agreement. ${ }^{165}$ Both annual agreements and terminable agreements are subject to a number of common conditions, the most important of which are those related to assessment of the land, inclusion of the parcel in the assessment roll, and provisions relating to duration (this latter is addressed in a subsequent section). The land assessment provisions are designed to ensure that the land is practically and economically irrigable.

\section{Househol. Purposes Agreement}

As its name suggests, the household purposes agreement (HPA) authorizes the delivery of water for household purposes. "Household purposes" are defined in s. I(p) as "the use of a maximum of 1250 cubic metres of water per year per household for the purposes of human consumption, sanitation, fire prevention and watering animals, gardens, lawns and trees."166

\section{RURAl, WATER USF, AGREEMENTS}

Added to the $A c t$ in $2002,{ }^{167}$ the term "rural water use agreement"is less self-explanatory. The $A c t$ in s. $1(\mathrm{~mm} .1)$ defines a "rural water use" as

the use of a maximum of 25000 cubic metres of water per year per user for any purpose other than

(i) household purposes.

And this is a true Hohfeldian right, the ID bearing the correlative duty: Joseph William Singer, "The Legal Rights Debate in Analytical Jurisprudenee from Bentham to Hohfeld" [1982] Wis. L. Rev, 975. This is the language used in each of ss. $16(2), 17(2), 19(2), 19.1(2)$, and $21(2)$; this language is much closer to that of a liberty, i.e., the ID commits no wrong by entering into such an agreement (Glanville Williams, "The Concept of Legal Liberty" (1956) 56 Colum. L. Rev. 1129).

$I D A$, supra note 2, s. $16(2)$ : "An annual agreement authorizes the delivery of walter through the irrigation works of the district to that parcel for irrigation purposes."

Ibid., s. 17(2): "A terminable agreement authorizes the delivery of water through the irrigution works of the district to that pareel for irrigation purposes." For the predecessor section, sece Irrigation Act. R.S.A. 1980, c. I-II, s. 50. Terminable agrecments under that $A C$ were terminable on one month's notice.

This would seem to follow from the language of $s$. 19(4) (and sec also s. 15), which confers an exemption only on water delivered to "irrigation acres."

The term "household" is further defined by reference to regulations under the Water Act: sce Water (Ministerial) Regulation, supra note 44, s. 1(3)(b). For the predecessor seclion, see Irrigation Act, supra note 164. s. 51 describing the arrangement as a "privilege."

S.A. 2002 , c. 3. 
(ii) the irrigation of acres recorded on the assessment roll of the district, or

(iii) the irrigation of acres included in an alternate parcel irrigation agreement. ${ }^{16 x}$

To adopt some of the list of uses from s. 11 of the Waler (Ministerial) Regulation, ${ }^{169}$ this suggests that, at a minimum, an ID can use a rural water use association (RWUA) to provide water for any or all of the following purposes: municipal, agricultural, commercial, industrial, water power, fish and wildlife management, habitat enhancement, and recreation (or, to put it another way, the universe of possible uses mimus houschold and irrigation purposes) - subject of course to the volume limits that the $I D A$ imposes.

There is nothing in the IDA that requires that the parcel of land on which the user will use water under a RWUA has to be "included in a district" before the district can enter into such an agreement. ${ }^{170}$

These then are the main forms of agreement under the $I D A$ that create entitlements to use water. Two other forms of agreement are, on the face of it, concerned with entitlements to use ID facilities and canals rather than entitlements to use ID licensed water. This is crystal clear in the case of a use of irrigation works agreement (UIWA) but somewhat more ambiguous in the case of water conveyance agreements.

WA, supra note 2. s. 1 (mm. I) [emphasis added]. In the context of the volumes of water arailable to IDs and used in irrigation this is not a large volume of waler. It represents $\left(25,000 \mathrm{~m}^{3} \mid \mathrm{yr}^{2}=25 \mathrm{dam}^{3} ; 1 \mathrm{dam}^{3}\right.$ $=0.81$ acre feet) approximately 20 acre feet. The proposed Fvan Thomas (reck (joll Course in Kananaskis, had a projected annual demand of 209 dam': see Natural Resources Conservation Board (NRCB), Kan-Alta Decision Report (August 1992), online: NRCB <www.nrch.gov.ab.ca/nrp/ Decisions.aspx? $+4=387>$ at 31 . A 5000 steer intensive livestock operation requires a reliable supply of $99 \mathrm{dam}^{3}$ per year and a 500 sow pig operation requires $37 \mathrm{dam}^{3}$ per year (D.R. Cooteand \& L.J. Gregorich, eds. The Health of Our Water: Toward Sustainable Agriculhure in Camada, Research Branch, Agriculture and Agri-Food Canada, Publication 2020/E (2002) at 134, unline: Agriculture and Agri-Food Canada <www.agr.gc.ca/nlwis-snite/pub/hw_se/pdf/intro_e.pdis). The reference to user (rather than per parel or per agreement) is perhaps important. it suggests an entity could not seek to enter into multiple RWUAs in order to meet its needs if those needs were in excess of 25,000 cubic metres per year. The inclusion of the volumetric limit in the delinition of a use seems unnecessary and problematic. It is unnecessary because the substantive provision itself(s. 19.1(4)) contains a volumetric limitation. II is problematic because it suggests the bizarre but possible reading that an agreenent that authorizes the use of a larger volume is not a nural water use agreement. Supra note 44.

170 This may depend upon the terms of the ID's licence. Certainly some ID licences authorize delivery of water for some purposes outside of the boundaries of the district: see discussion in suprea note 15 . The term "included in a district" is used in s. 75, which is in Part 4 of the Acr dealing with the creation. amalgamation. and change of area of districts. I infer that the "boundaries" of a district are delermined from time to time by "the parcels constiluting the district." On this view, the district therefore comprises the area of the ID) as initially accepted by the Minister plus or minus any parcels added to the district in accordance with the procedure prescribed in ss. 84 et sey. Examination of Part 5 of the Act dealing with assessment suggests a somewhat different conception of the district that is quite distinct from the sum of the pareels. I do not think that the Aer is completely consistent on this point. Note that the former Irrigation Acl, supma note 164 , used to contain a definition of a "district with outer boundaries" (s. I (g)). which referred to an ID "other than one consisting of the aggregate of the parcels on its assessment role" and see ss. 110-11. For judicial discussion of these older provisions. sec Chrdohiak y. Alberta (Irrigation Council) (1996), 39 Alta. L.R. (3d) 56 (Q.B.) [Chudobisk]. 


\section{USE OF IRRIGATION WORKS AGREEMENTS}

The UIWA authorizes the use of irrigation works for purposes other than the delivery or removal of water. It is self-evident, therefore, that a UIWA cannot create an entitlement to water for any use whatsoever.

\section{Water CONVEYANCE AGiREEMENTS}

A water conveyance agreement (WCA) authorizes the delivery of water for a variety of purposes or the removal of drainage water, stormwater, or wastewater. Before the $A C l$ was amended in 2002 to add the set of provisions dealing with RWUAs discussed above, the WCA authorized the delivery of water "to an area" "1" for any purpose other than irrigation purposes or household purposes. Under this scheme, the WCA had a broad potential area of application that might be described as: the universe of possible uses minus irrigation and household purposes.

The Irrigation ACl Amendment ACt of 2002"12 divided the "delivery" paragraphs of the WCA section of the $A c t$ into two separate paragraphs: (a) and (a.1). I quote the entire subsection to facilitate the discussion that follows:

(2) A water conveyance agreement may authorize

(a) the delivery of water through the irrigation works of the district to an area for a purpose other than

(i) the irrigation of acres recorded on the assessment roll of the district.

(ii) the irrigation of acres included in an altemate parcel irrigation agreement.

(iii) nural water use, or

(iv) household purposes.

(a. I) the delivery of water through the irrigation works of the district for any purpose specified in a water licence issued under the Waler Act, or

(b) the removal of drainage water, stormwater or wastewater from an area. ${ }^{13}$

Of the two "delivery" paragraphs, paragraph (a) now permits the parties to use a WCA for any purpose other than the enumerated uses. ${ }^{174}$ It is important to recall that the $A c r$ defines rural water use as the use of water for any purpose other than household or the two forms of

17 This section uses the general and undefined term "area" rather than the more technical and defined term "parcel." While it is somelimes difficult to identify the precise antecedents of a provision in the former Irrigation Act, ibid, the tollowing are of some interest: (1) s. $44(1)(\mathrm{c})$, which stipulates that the powers of the Board of an ID include the power to "act as a carrier ol" water to be used within or outside the district for any purpose and use its irrigation works for that purpose"; and (2) s. 52, which seems to implement this power by indicating that a board may enter an agresment with a person to supply water for a non-irrigation purpose. Section 52(2), however, provides that "the board shall not supply waler under the agreement until the other party to the agreement has complied with the requirements of the Water Resources Act and regulations thereunder." And see in this context, Friends of the Ollmum. stipres note 13 at para. 18.

17: Supra notc 134.

131 WA, supra note 2, s. 21 (2) [emphasis added].

134 Note that this is not the same as irrigation acres. The term "irrigation of acres recorded on the assessment roll" includes not only irrigation acres but also parcels that contuin acres subject to a terminable or an annual agreement (IDA, ibid., s. 93(a)). This usage is quite deliberate, in lact the 2002 amendment was lurther changed in 2003 (S.A. 2003, c. 42, s. 10) to drop the term "irrigation acres," which had been used in the original 2002 amendment, stipros note 134. 
irrigation referred to above (i.e., the universe of possible uses can be expressed as rural water use + household + irrigation of acres on the assessment role + irrigation under an alternate parcel irrigation agreement). Under this scheme the potential area of application of the WCA under this paragraph has been dramatically narrowed to the point where it is not clear that paragraph (a) permits any rational application. The paragraph can now be formulated as: the universe of possible uses mimus (rural water use + houschold + irrigation of acres on the assessment role + irrigation under an alternate parcel irrigation agreement (a combination that we have just defined above as the universe)).

In sum, paragraph (a) seems to have created an absurdity. While one should no doubt strive to avoid such an interpretation ${ }^{175}$ it is difficult to offer an alternative reading of the $A c t$ given the logical formulations ("purposes other than") that the legislature has chosen to adopt and the Act's extraordinarily broad definition of "rural water use."176

The second "delivery" paragraph is somewhat more cogent since it authorizes the delivery of water "For any purpose specified in a water licence issued under the $\mathrm{Warer}$ Act." 17 The section does not tell us whether this paragraph is referring to a licence held by the ID, a licence held by the person who is taking delivery of the water or, conceivably, by either one of those parties. Let us explore the implications of these options. The interpretive point is important. If paragraph (a.1) refers to the ID's licence, then it would seem to follow that the WCA itself provides sufficient authority for the ID to divert and deliver water. If (a.1) refers to a licence held by the person to whom water is to be delivered, then it is that licence that authorizes the diversion and use of the water and the WCA merely authorizes that licensec and the ID to use the ID's facilities for that additional purpose.

I think that the latter interpretation is preferable for several reasons. ${ }^{178}$ First, the preferred interpretation helps to make sense of the alternative formulations of the scope of the WCA contained in paragraphs (a) and (a.1). I think that I can show this with the following example. We can take it for granted that all IDs will hold licences that, at a minimum, authorize use of diverted water for irrigation purposes; yet paragraph (a) expressly precludes the ID from using a WCA to deliver water for irrigation purposes. However. an interpretation of (a.1) that would have it refer to the ID's own licence would thence allow what paragraph (a) had just precluded - certainly inelegant if not absurd.

Second, if the WCA can be used by an ID to confer on a third party the right to use a part of the ID's licensed entitlement for a non-irrigation purpose, then there is little reason for the Act to provide alternative forms of agreement such as the domestic and rural water use agreements. The WCA could then be used to get around the volume, duration, and priority limitations that apply to these other forms of entitlement.

Ruth Sullivan, Dreidger on the Comsenction of Stomits. 3d ed. (Toronto: Bullerworths, 1994) c. 3. Indeed the only alternative formulation $I$ can come up with is one that I described above (supro note 168 ) as equally bizarre, i.e., the suggestion that a WC $A$ miglat be used to authorize delivery of a volume that exceeds that which might be delivered under an RWUA. If this were indeed the intent, we might expect this result to have been expressed more directly and explicitly. 
Third, the title of the agreement itself suggests the agreement is designed to authorize water to be conveyed (i.e., carried) through the ID's facilities.

Fourth, unlike the provisions that pertain to the other forms of agreement, the WCA section provides the applicant for a WCA with a right of appeal to the Irrigation Council. This suggests that an applicant has an expectation entitlement that is not shared by the applicant for any other form of subsidiary agreement under the IDA. Such an appeal makes sense if the issue is simply the "right" to use the works of the ID. It makes less sense if this is an appeal that goes to the right to receive water. Or, 10 put it another way, if the legislature wanted to create an appeal right where the ID refused to supply water to an applicant, one would expect that appeal right to be afforded equally to applicants under all of the forms of agreement. There must then be something distinctive about the WCA and I argue that, unlike the other agreements, the WCA does not create an entitlement to a share of the ID's water but merely authorizes a third party to use the ID's works.

Fifth, the WCA section includes a "compliance with laws" clause which provides that:

[T] he distriet must not deliver or remove water under the [waler conveyance] agreement until the other party to the agreement has complied with the requirements, if any, of the Water Act, the Environmental Protection and Enhancement $\mathrm{Acl}$ and the regulations under those Acts. ${ }^{179}$

This section is consistent with the idea that the person taking delivery must have an independent right to the water. ${ }^{180}$

There is a contrary argument in favour of the WCA as an independent right. This argument emphasizes that the $A c t$ uses exactly the same formulation to describe each of the agreements that we have been looking at, other than the rights held by the irrigator of irrigated acres. That is to say, in each case the $A c t$ uses the formulation: "an xyz agreement authorizes the delivery of water through the irrigation works of the district for xyz purposes." In the case of most of the agreements, it is crystal clear that the ID is delivering a portion of its own licensed entitlement and, since the legislature has chosen to use the same formulation in s. 21 for the WCA, the same assumption must hold. ${ }^{181}$

1.4 IDA, supra note 2, s. 21(6).

150 It is also consistent with what appears to be (see supra note 163) this section's predecessor provision in the former Irrigation Act, supra note 164.

IxI But it is clear that the mere conferral of authority does not in and of itself answer the question or what other rules may be relevant. See in this context Hunt J.A.'s judgment in Friends of the Oldman River. supra note 13 at para. 18, where she states (dealing with the possibility that an ID might need to construct new works to take advantage of a licence) that

the authorily thus granted [by s. 44 of the former Irrigation Act] is merely permissive. It can only be exercised in accordance with the requirements of the Water Resources Act and the Regulations. Otherwise, the Minister of the Environment and the Controller of Water Resources would lack the kind of planning and supervisory functions that the Water Resources Act requires them to have, in order to make decisions about the use of waters in the best interests of all citizens of the province, not only those who require water for irrigation purposes.

And to the same effect emphasizing the permissive nature of s. 44 see Chudobiak, supra note 170 at para. 32. 


\section{What Priority Is ACCorded to Each of tile Derivative Ricits?}

The IDA addresses questions of priority as between at least some categories of entitlements. ${ }^{182}$ As one might expect, irrigation acres receive first call on the water available to the ID:

A district may stop the delivery of waler to a pareel subject 10 an annual agrecment or terminable agreement if the district is of the opinion that it may not be able to deliver sulficient water to the irrigation acres of the district or to the irrigation acres in a portion ol the district. ${ }^{\text {IS. }}$

The section goes on to provide that, where it is necessary to stop delivery, the District shall do so first by stopping delivery to acres in a parcel subject to an annual agreement, and second to acres in a parcel subject to a terminable agreement. The $A c t$ provides no guidance as to relative priorities within each of these categories. Thus, while an ID presumably cannot cut off water to any terminable agreement acres ${ }^{184}$ unless it has first stopped delivery to all annual agreement acres, the $A c t$ does not tell us whether the ID has to prorate delivery to all users in a particular class or whether it can apply a different decision criterion. ${ }^{185}$

There may be some difficult issues associated with the priorities that altach to the different licences of an ID. An ID will often have several licences each with a different priority date. As an ID acquires more water under suecessive licences it is able to expand and add irrigated areas. However, the water acquired under these later licenees may have a lower priority than that claimable by other licensees. Question: do all the holders of irrigable acres have the same claim to priority no matter what the priority of the licence which was in effect when that irrigable acreage was added to the roll? The practice of the IDs is Io treal all irrigable acres in the same way. At the stan of the irrigation season the ID will typically assess (based on snow pack and neservoir levels. etc.) the maximum amount of water that it expects to be available for each irrigation acre. This may be subject to adjustment as the season progresses. See para. 3.4 of the EID's Approved Pracrices and Guidelines, supra note 159.

IDA, supra note 2, s. 13(2).

154 At least within that part of the ID.

1N: Much might depend upon the extent to which IDs are to be viewed as analogous to public utilities. While s. 191 of the $A c$ limits the application of the Public Unilities Bourd Act. R.S.A. 2000, c. P-45 [PUB ACt] to IDs, the analogy to utilities might still prove persuasive. There is some reason lor thinking that the IDA adopts at least a version of some of the disciplines that typically apply to public utilities: sec. e.g.. s. 115(2) referring to the determination of fees for some calegories of subsidiary agreements on a "Fiar and equitable basis" (the typical utility standard is "just and reasonable"). and s. 118 stipulating that an ID must establish an irrigation rate, an annual agreement rate, and a terminable agreement rate that must apply to cach of the acres within that category of a district or at least to an established part of a district. Section 63 of the former Water Resources Act, supra note 10, used to impose on licensees who were "under obligation to supply water conveyed by his work" a duty not to discriminate and a duty to proration supply in times of shortage. Should the utility analogy prove persuasive, one would expect an ID to have a duty not to engage in unjust discrimination at least as between users in the same calegory. The language of the exemption is actually rather curious since. instead of simply exempting IDs from the PUB ACr, s. $19 \mid$ of the $I D A$ stales that the PUB ACt "does not apply in respect of any matler arising in connection with an agreement entered into. a bylaw or regulation made or any rate. charge or fee imposed by a district under this Act." Litigation under the former Irrigation Act, supra note 164 suggests that in practice ID's have considerable discretion in creating different calegories of service and different charges for those services. See in particular the series of cases between Westem Irrigation District and landowners contiguous to Chestermere Lake, stupra note 155. Other water providers are subject to the disciplines of utility regulation. Sec, e.g. Alberta Energy and Utilities Board (AEUB), Interim Decision U99131: Clear Wher Unlimited Inc. 722924 Alberta Lid. 762265 Atheria Limiled \& Decrhaven Estates (21 December 1999), online: AEUB <www.cub.ca/docs/documents/decisions/1999/ u99131.pdf?. 
While the Act does not expressly address the priority of other categories of entitlement, it does so indirectly insofar as most other forms of rights to water (as opposed to the right to use facilities) are terminable either annually or on relatively short periods of notice. In effect, therefore, the $A c t$ establishes a fairly crude purpose-based priority system that might be loosely stated as follows: (1) irrigation water for irrigated area; (2) irrigation water for annual agreement acres; (3) irrigation water for terminable agreement acres; (4) water for "rural water use"; and (5) water for household purposes. ${ }^{186}$ But this can be nothing more than a loose priority system, since, while the $A c t$ is clear about the dominance of (1) and about the relative priority of categories (2) and (3) as between each other, it does not in fact instruct a district as to whether categories (2) and (3) take priority over categories (4) and (5). ${ }^{1 / 7}$

\section{What Is the Duration of Each of the Derivative Rights?}

As we have seen in the previous two sections, the only form of entitlement under the IDA that offers real security to its owner (in the sense of priority of entitlement) is the right associated with the designation of "irrigation acres." The duration of the entitlement offers another dimension of the security of the derivative right. Here, in summary form, is what the $I D A$ has to say about the duration and termination of the various categories of entitlement:

- Irrigation acres. The rights associated with irrigation acres continue for so long as the parcel is included in the assessment role (s. 14). ${ }^{1.8}$

Annual agreements. An annual agreement expires automatically at the end of the calendar year (s. 16(3)(d)) but is also liable to interruption on 24 hours' notice at any time (s. 13(4)) in the event of shortage.

- Terminable agreements. A terminable agreement is terminable at the option of either party on notice before 1 March in any calendar year $(s .17(3)(d))^{189}$ but is also liable to interruption on 24 hours' notice at any time (s. 13(4)) in the event of shortage, provided that deliveries to annual agreement acres have already been terminated.

The only reason for ranking a HPA below a RWUA is that, while a HPA is terminable at any time on 60 days notice, a RWUA is only terminable once a year before I March of that year.

See discussion in the next section of the extent to which persons holding rights under a RWUA, for example, might be able to contract for priority delivery.

iss The procedure for removing a parcel with irrigation acres from the ID is set out in the /DA. stupra note 2. 5. 87. The ID must give at least one year's notice and the ID's decision can be appealed to the Council. Furthermore, it appears as if the irrigator will. under certain circumstances. have a right to compensation for the loss of irrigated acres. For a case dealing with deletion of parcels from an ID under the former Act, stupra note 164, see Cluctobiak, supra note 170 .

inv The ACl does nol prescribe the maximum duration of such an agreement but if all agreements are terminable at the instance of the ID it is hard to imagine if there is any significant difference betwecn a terminable agreement for two years or 20. Neither does the $\mathrm{Ac}$ prescribe the amount of notice that need be given. Presumably, notice delivered on the last day of February of any year is a valid notice 10 terminate the delivery of water effective 1 March of that same year. That said, as a praclical matter, this would be well before the stan of the irrigation season in any year. 
- Household purposes agreement (HPA). A HPA is terminable at the option of either party on at least 60 days' notice $($ s. $19(3)(\mathrm{b})) .^{190}$

- Rural water use agreement (RWUA). A RWUA is terminable at the option of either party on notice before 1 March in any calendar year (s. 19.1(3)(b)). ${ }^{191}$

- Use of irrigation works agreements. The $A c t$ is silent on the duration of an IWA but the references to registering the IWA on title suggest that such agreements are intended to be long term and are clearly intended to bind the land.

- Water conveyance agreements. The $A c t$ is completely silent on the duration of a WCA, implying that an ID could enter into a WCA for a short or long term or conceivably in perpetuity.

Where the $A c t$ establishes a duration (or termination) requirement, it does so in very prescriptive terms. The relevant language in each case states that an agreement of the particular category is "subject to the following: ... that the agreement provides that it is terminable." $1 \% 2$ This suggests that there is very little, if any, opportunity for the parties to contract out of these termination arrangements. Thus, an agreement that provides a different termination arrangement or an irrevocable option to renew would be void or, more likely, simply unenforceable. ${ }^{193}$.

\section{E. IDS AND TEMPORARY AGREEMENTS TO ASSIGN WATER UNDER THE WATER ACT}

Now that we have a clearer understanding of the forms of rights that are available under the $I D A$, it is appropriate to return to a question that we broached earlier; namely, can IDs enter into agreements to assign water under s. 33 of the Water Act? This is a question of interpretation of the IDA rather than the Water Act since the Water Act contemplates that all licensees and traditional users may enter into such an agreement. The IDA itself does not address the issue explicitly. What then is the implication of silence? The most obviously relevant provision is s. $6(2)$ of the IDA which provides that an ID "has the capacity and, subject to this Act, the regulations and the bylaws, the rights, powers and privileges of a natural person." We know that a natural person has the capacity, right, and power to enter

This is an extraordinarily shor notice period for cutting off domestic water supply and surely confirms the dominance of irrigation values in the IDA.

The comment in the previous note is equally applicable here. And. once again, given that a municipality may enter into a RWUA to secure a water supply for residents of the municipality, the ability to terminate such an dgreement on such short notice is either draconian or should simply be a warning to a municipality that it should seck to acquire its additional water rights by way of a transfer rather than depend upon the vagaries of a RWUA.

See IDA, supra note 2. ss. 17(3)(d). 19(3)(b). 19.1(3)(b); see also s. 16(3)(d). Sec also s. 15, which provides that: "Where a district enters into an agreement for a purpose specified in [the relevant sections]. the district must do so in accordance with that section"; i.e., an ID cannot do indirectly what it cannot do directly.

See the discussion in the next section of the capacity of an ID to enter into a s. 33 assignment agreement. A similar fate would likely befall more indirect methods to attain greater security (e.g., a clause of a RWUA which propided that the ID would not give notice to terminate the RWUA unless it had first terminated or failed to renew annual agreements or terminable agreements). 
into any agreement (save an illegal contract), ergo an ID must be able to enter into an assignment agreement. The snag with this argument is obviously the "subject to" language of the subsection. ${ }^{194}$ Focusing on the $I D A$ then, is there any provision of the $A c t$ that limits this capacity, right, or power? Certainly, there is nothing as obvious as the prohibitory language of s. 11: "No district may make an application for a transfer." But on the other hand. the general scheme of the $A C$ seems to be that no person may acquire an entitlement to a share of ID water except in accordance with one of the prescribed agreements. Section 15 of the IDA reinforces that impression when it provides that where an ID enters into an agreement that is covered by the purposes of one of the listed agreements (e.g., RWUA, HPA, WCA), the district must do so in accordance with the relevant section of the Act.

And it surely does not matter that a s. 33 agreement is a temporary arrangement, for so are many of the derivative agreements (e.g., annual and terminable agreements) prescribed under the $I D A$. In fact, it is hard to imagine a s. 33 agreement to assign water that did not serve directly or indirectly one of the purposes of the listed agreements. In sum, we reaffirm our earlicr conclusion to the effect that the various provisions of the IDA dealing with different forms of agreement that an ID can enter into do not themselves preclude an ID from entering into a s. 33 agreement but, in order for such an agreement to be enlorccable, it will also have to fall within one or more of the existing $I D A$ categories of agreement and comply with the relevant provisions of the $A c t$ in relation to those agreements. ${ }^{195}$

\section{F. The TransFerability OF ENTITLEMENTS UNDER THE IRRIGATION DISTRICTS ACT}

We are now in a position to consider the third level of analysis under the $I D A$. To what extent are the derivative entitlements that we have been discussing transferrable by the holders of those entillements? The $I D A$ expressly addresses the transferability of three forms of entitlement (the right of irrigators with respect to irrigated acres, and annual and terminable agreements) but it is silent with respect to HPAs and RWUAs.

\section{IRRIGATION ACRES}

In a scheme that bears some superficial similarity to the two-fold assignment and transfer scheme of the Water $A c t$, the $I D A$ contemplates that an irrigator may alienate his or her entitlement in one of two ways: ${ }^{1 \%(}(1)$ a seemingly permanent transler of irrigation acres; or

Interestingly, the "subject to" language does not qualify the word "capacity." It would, however, be unwise to make too much of this insolar as capacity may be thought of as a basket term to deseribe the sum of legal entitlements or Hohfeldian relationships that a person may have. It might also mean that an ID entering into an assignment agreement might need to insist upon the inclusion of a clause giving the ID the right to interrupt delivery on 24 hours notice (see IDA, supra note 2. s. $13(4)$ ).

1 This is not exhaustive of the llexibilities available to irrigators. l'or example, an irrigator might elect to sell irrigation acres and the s. 14 rights of the irrigator would pass with the land title. See also s. 23 of the Act refierring to the concept of an "irrigable unit" which appears to be a mechanism whereby an irrigator can effectively group irrigation acres with other land in the same or a contiguous pareel. Under the former Irrigation Act, supra note 164, there Were no comparable provisions authorizing temporary or permanent transfers. The predecessor provision dealing with "irrigable units" was $\$ .58$, which made it plain that once lands had been grouped as an irrigable unit. a sale of anything less than the entire unit required the ID's consent. 
(2) a temporary alternate parcel irrigation agreement. Both arrangements however are subject to the discretionary authority of the ID to approve or reject the proposed transfer. ${ }^{197}$

\section{a. Transfer of Irrigation Acres}

Section 26(1) of the IDA contemplates that an irrigator may apply to the ID "to transfer irrigation acres to another parcel if the parcel that is to receive the irrigation acres is served or is capable of being served by the same district." 198 An application may be made to transfer irrigation acres, either to other land of the same owner or to land owned by another party. In the case of the former, but not the latter, the application must be accompanied by evidence that establishes that any mortgagee shown on the certificate of title for the parcel from which the irrigation acres are being transferred consents to the transfer. ${ }^{199}$

A board of an ID may establish a date by which applications to transfer irrigation acres must be received in any year. ${ }^{2(0)}$ The $A c t$ requires the ID to provide a general public notice of this date and also requires the ID to "give written notice of its decision to approve an application"201 containing a statement of the right to appeal to the Irrigation Council. While the italicized phrase seems to suggests that notice (and the right to appeal) is only required when the ID approves an application, the appeal provision itself provides that an appeal may

For a useful review of the actual practice of one ID (SMRID) see Nicol, supra nole 25. Nicol's work covers the 20013 irrigation season. Based upon participation in her survey, Nicol identified 151 buyers and 114 sellers participating in the market. Unfortunately for my purposes, Nicol's terminology does not track that of the Act. Thus, at 60 , she uses the language of "water allocation transfer form." Ilowever. $\mathrm{I}$ infer from her discussion that she must be referring to APIAs rather than TIAs. Interestingly, Nicol also suggests that there were several examples of irrigators translerring water among users within three districts, SMRID, Raymond, and the Taber Irrigation District. The $/ D A$ does not address this possibility. These two categories are, of course, very different. If the parcel is already served then it must be part of the district and must qualify as land that is suitable for irrigation. If the land is merely capable of being served then it would seem to follow that an application to transfer should also engage ss. 84 et seq. of the IDA, which deals with "the addition of a parcel to or the removal of a pareel lrom" an ID. Where a transfer requires an extension lo existing works in order lo deliver water, the application may then require not only an upplication to add lands to the ID but potentially also a remole delivery agreement with a cost sharing nrrangement with the ID for the incremental cosis of the exlension (s. 24).

This technical requirement (and one that seems to put the ID in tlic ruther odd position of protecting the interests of third parties who ought to be well capable of protecting their own interests) speaks volumes about the way in which we have historically viewed irrigation rights as something inseparable from the land. If irrigation rights were readily separable, a creditor would register its security against the irrigation right rather than against the land title. Sections 91.93 of the $I D A$ require each ID to maintain an assessment roll that must contain a listing of irrigation acres and acres subject to a terminable agreement but the assessment roll is primarily used to determine liability for fees and charges. The roll does not serve as a registry system; a bank cannot register security against the assessment roll of an ID. Section 142 of the $I D A$ and related sections (e.g. ss. 20, 23. 24) confirm this analysis insolar as they use the Land Titles Act, R.S.A. 2000, c. L.-4, to assist in enforcing unpaid charges and fees. Thus, both the ID and mortgagees can enforec their security but only against the land to which the irrigation acres are "appurtenan" (the 10A itself dows not use the language of appurienancy). As yet, irrigation rights are insufficiently fungible for a creditor simply to take a security interest against the walter right.

IDA, silpra note 2, s. 26(4). This is not a precondition to the ability to apply to transfer and il an ID has failed to set a specific date the presumption must be that an irrigator may lile his or her application at any time. 
be commenced by an applicant ${ }^{202}$ where an ID "makes a decision ... to transfer or to refuse to transfer irrigation acres under section 26."203

The Act provides no guidance as to the factors that an ID should take into account in passing upon an application ${ }^{20-1}$ and does not require the ID to provide reasons for its decision. Furthermore, unlike the comparable provisions of the Waser $A c t$, the $I D A$ does not explicitly address whether a transfer must be perpetual, or whether it can be made for a fixed term or other term known to the law such as for the life of a person. That said, the final subsection of $\mathrm{s}$. 26 deals with the consequential amendments required to the assessment role where the ID elects to approve an application. ${ }^{205}$

At least some of Alberta's 13 IDs have developed policies that will inform the way in which they review applications to transfer irrigation acres. ${ }^{206}$ The SMRID policy, for example, deals with such things as deliverability considerations, the minimum size of retained blocks, and prohibits the transfers of acres from a rehabilitated part of the system to a non-rehabilitated part of the system. ${ }^{207}$ The Bow River Irrigation District has notified members that the District itself will enter the market to purchase irrigation acres should irrigators wish to reduce their acreage. ${ }^{\text {tox }}$

\section{b. Altemate Parcel Irrigation Agreement}

The Alternate Parcel Irrigation Agreement (APIA) is evidently a shorter term version of the Transfer of Irrigation Acres (TIA). In the case of the APIA, duration is governed by s. 25(6) of the $I D A$, which stipulates the minimum content of an APIA and provides that an APIA must specify that "the term of the agreement commences 1 May and expires on 31

This section secms to make it clear that it is only the applicant that has standing to commence such an appeal since in other cases the statute creates a broader class of potential applicants.

IDA, supra note 2 , s. 167 (1)(b)(ii).

Unless of course, the application is to transfer acreage to a parcel that is not being irrigated and if, as suggested above (supra note 198), the application also requires an application to change the district area, in which case s. 84(4)(a) suggests that the ID must at least have regard to the risks that "it is impractical, uneconomical or undesiruble to deliver water" [emphasis added] (the term "undesirable" seems to give the ID a very broad discretion). This decision, too, is appealable to the Imigation Council although. interestingly enough in this case, any person who files an objection to the notice of the application (which the Act requires be published in a newspaper of general circulation in the ID) has standing to commence an appeal (ss. 167(1)(b)(i), 85, 86).

It is hard to draw a definitive conclusion from this provision. On the one hand, it secms to suggest that the transferor retains no temporal interest (the transferor may of course retain some irrigated acres) in the transferred acres but, on the other hand, this may simply be a provision designed to facilitate record keeping for assessment roll purposes.

This and the similar section pertaining to APJAs is based upon a review of the policies for SMRID and the EID. These are the only Iwo IDs that maintain reasonably comprehensive web sites and post at least some of their more important policies on the site.

The policy sets the minimum relained unit as $\mathbf{3 0}$ acres. SMRID also has a policy pertaining to the socalled moratorium list, which has some implications for transfers. The moratorium list is a list of applications by persons who want to add acreage to the ID should the ID be able to secure "more" water through conservation or other mensures. Clause 10 of the SMRID Moratorium List Policy, online: SMRID <WWW.smrid.ab.ca/moritori.htm>, requires that an applicant for new acreage must enter "into an agreenent not to commercially transfer the water right under Section 26 of the IDA from the land for a period of five years from the time the land is added to the assessment role."

Bow River Irrigation Districl (BRID). Waler Information Newsletter, Issue No. 20 (June 2004), online: BRID <www.brid.ab.ca'files/Junc2004Newslenter.pdl>. 
December of the same year." The $A c t$ does not preclude the possibility that the parties to an APIA may agree to renew the agreement in successive years but in each case the ID would need to approve the renewal arrangement.

In addition to duration there are a number of significant differences between the APIA and the TIA. The Act is generally more prescriptive in relation to an APIA than it is in relation to a TIA. Common features include the following: (1) ID approval is required; (2) the arrangement may pertain to another parcel owned by the assignor or to a parcel owned by a third party; (3) the ID may prescribe an annual deadline for applications and publish that deadline; and (4) the arrangement is subject to some practical deliverability test. ${ }^{204}$

The key differences are the following: (1) An application for a TIA results in the ID approving or not approving the application, subject to appeal rights. In the case of the APIA there is no right of appeal and, if the ID approves the arrangement, it is the ID that enters into the APIA with "the irrigator" (i.e., the transferor); ${ }^{210}$ (2) Given that the assignor's irrigation interest will not be extinguished in the case of the APIA, several of the conditions in the APIA subsection (s. 25(6)) are designed to ensure that the arrangement does not result in "double-dipping" by the assignor; (3) While we saw that the TIA clauses of the Act did not explicitly provide for an assessment and classification of the transferee's parcel, this is required for the assignee is parcel in the case of an APIA (s. 25(5)(b)); and (4) Since an APIA is temporary and the assignor retains an interest, an APIA does not result in a change to the assessment roll although the ID is required to keep a separate record of APIAs.

As with the TIAs, the SMRID policy on APIAs notes that ID approval may require a review of canal capacity! The Eastern Irrigation District (EID) seems to impose additional restrictions. Thus, cl. 3.4/2 of the EID's Approved Practices and Guidelines suggests that in any year where the EID sets an allocation that is less than the stipulated maximum (24 inches per acre) "irrigators will be permitted ... to optimize their water allocation by pooling their total allocation ... and transferring it from one parcel to another parcel owned by the same irrigator."211 The policy continues by stipulating that in a year where the ID does not set a lower allocation "irrigators will not be permitted to pool and/or transfer any of the water provided for to them for irrigation purposes." 12 This seems more restrictive than the $I D A$ contemplates, and is perhaps an unlawful fettering of discretion. ${ }^{213}$

In sum, the IDA expressly addresses the transferability of the irrigator's entitlement through these two forms of arrangements. It bears emphasizing that these would seem to be

There is a surprising lack of symmetry in the language here. In the case of the TIA, the test is framed in terms of the parcel being served or capable of being served and as a pre-condition to the application (s. $26(1))$. In the case of the APIA, the test is framed as an assessment by the ID that "the district is able to deliver water to the alternate parcel" and as a precondition to approval by the ID (s. 25(5)). Perhaps nothing turns on these minor differenees but it begs the question why the drafter elected to use symmetrical language for some parts of these iwo stelions but not others.

IDA, stupra nole 2. s. 25(5). This is all that will be required if the irrigator owns both parecls. In other situations, one would expect there to be an additional agreement between the two parties. The Act is silent on this matter and is also silent on the issue of third party mortgagees in relation to APIAs. Approved Practices and Gividelines, supra note 159 at 3.

213 On fettering generally, see David Phillip Jones \& Anne S. de Villars. Principles of Administrative Lan, 4th ed. (Toronto: Carswell, 2004) at 192 er seq. 
the only types of transfer in which an irrigator can engage. The IDA does not authorize an irrigator to transfer its entitlement to a person wanting to use the water for a non-irrigation purpose. Consequently, a transfer to a higher value user such as a vegetable processing operation would need to be effected by the ID itself rather than by the owners of irrigable average entitlements.

\section{ANNUAL AND TERminABl. AgREemENTS}

The $A c t$ addresses transferability in relation to annual and terminable agreements by stipulating that the provisions dealing with the alternate parcel irrigation agreements and transfers "do not apply to acres subject to an annual agreement or a terminable agreement."214 By implication the rights under these agreements are therefore not transferable.

\section{HPAS AND RWUAS}

As stated above, the $A c t$ is silent on the transferability of these two types of agreements. The matter is therefore subject to the general law of contract, which suggests that (subject to the terms of the particular contract $)^{213}$ while the benefit of a contract may be assignable, the burden is not assignable absent an assignment and novation agreement involving all of the parties. ${ }^{216}$ Furthermore, any assignment that resulted in a change to the obligations of the ID (e.g., a change in the point of delivery) would require either an amendment or a supplementary agreement (e.g., a water conveyance agreement) with the ID. In practice, therefore, it would seem that these problems, combined with the relatively short duration of such agreements, will make them unassignable. It seems far more likely that an ID would enter into a new agreement directly with the potential transferee.

\section{G. Conclusions}

The 13 Irrigation Districts in Alberta control significant volumes of water within the SSRB. IDs can enter the water market in several ways. They can engage in s. 81 transfers under the Water $A c t$ as has the United Irrigation District. Alternatively, they may seek to expand the purposes for which they can divert and use water by amending their licences ${ }^{217}$ and provide a portion of their licensed water to a variety of users including golf courses, industrial plants, conservation organizations, and municipalities through a variety of agreements sanctioned by the $I D A$. Unlike transfers under the $W$ ater $A c t$, these arrangements are not subject to public review. But these arrangements also offer the transferees far less security of supply than that obtainable by a transferee under s. 81 of the Water Act. Furthermore, the language of the $I D A$ would seem to preclude the parties to these agreements from bargaining for a greater measure of security. Within the scheme of the $I D A$, only the holders of irrigable acres have meaningful security. The owners of such rights now have the opportunity to trade that entitlement either permanently through a transfer of irrigation acres

21. It would of course be possible for an ID to develop a standard form agreement which provides that an agreement was: (1) not assignable; (2) not assignable without consent: or (3) not assignable without consent, such consent not to be unreasonably withheld. 
or seasonally through an alternate parcel agreement, but they cannot transfer their entitlement to a non-irrigation user, either permanently or seasonally.

\section{Conclusions}

Alberta faces conditions of water scarcity. Scarcity requires that we adopt some mechanism for allocating and reallocating the resource. The Water Act and the Irrigation Districts Act each provide a regime within which the market may reallocate existing water rights. In this article, 1 have examined the main forms of water rights available under each of these two statutes and also examined the rules that apply to the transfer or assignment of those rights. I conclude the article with some more general observations about the Alberta scheme organized around the key themes that emerged from my review of the literature on water transfers and the marketing of water in Part II, above.

\section{A. FORMAL AND INFORMAL TRANSFer REgimes}

There is no single "transfer regime" in Alberta. Instead, both the Water Act and the IDA offer different mechanisms for reallocating water rights. Some of these mechanisms are more formal than others (e.g., the s. 81 transfer is far more formal than the s. 33 assignment procedure), but all are in some sense "formal" insofar as each is authorized by the relevant legislation and each has the potential to be enforced by the dominant legal system. None of the schemes canvassed here depend upon customary norms that exist outside of the dominant legal system and therefore none depend for enforcement solely on the reputation of individuals and trust within the irrigation community.

The distinction between formal and informal transfer regimes is therefore not a useful distinction in the Alberta context, although it may draw attention to the idea that there is a spectrum of possibilities attended by different levels of formality.

\section{B. Transaction Costs}

The market for water rights in Alberta is a thin, low volume market that is only beginning to emerge as a result of relatively recent changes to both the IDA and the Water Act. One would therefore expect that parties to these arrangements might incur significant transaction costs, both administratively-induced as well as policy-induced. ${ }^{218}$ Perhaps the most important point to make here is that policy-induced transaction costs will likely only be significant in the context of s. 81 transfers. Section 33 assignments may inevitably incur what the literature refers to as "administratively-induced" transaction costs (e.g., matching the parties to the assignment) but there should be no policy-induced costs (i.e., the costs of complying with governmental approval procedures) for the parties to the arrangement since there is no need for prior regulatory approval of the arrangement. Transactions within an ID and pursuant to the terms of the IDA may incur limited policy-induced transaction costs, but these will be of a different order than those incurred in a s. 81 transfer. The approval of the ID is required to protect the economic interest of the District; the approval of the Director in the case of s. 81 transfers is required in order to protect the broader public interest and the interests of third 
parties. These differences in transaction costs, as well as exposure to a "good standing" assessment, the conservation holdback, and the conversion of the licence from a licence without term to a renewable interest suggests that potential transferees may exhibit some preference for avoiding s. 81 transfers if they are able to acquire rights with sufficient security through some other means. Whether they can do so is the subject of the next paragraph.

\section{Benefits, Costs, Third Pakty EFFects, AND THE ROI.E OF WATHR USE ASSOCIATIONS}

The various transfer regimes discussed in this paper are designed to allow water to be reallocated to higher value uses over time with resulting efficiency gains. The analysis here suggests that the role of the IDs may prove to be pivotal in terms of realizing these benefits yet it is by no means clear that they will able to fulfill this role, both with respect to the market that is internal to the ID but also with respect to the external market. With respect to the former, one would certainly anticipate that the IDs should be able facilitate market transactions within the district since the ID will, at a minimum, make it easier to identify and match buyers and sellers and provides the physical infrastructure for effecting transfers. But we must recall that the $I D A$ places serious limitations on the forms of rights that an ID is able to offer a potential purchaser. Thus, there may be no match between the priority and security needs of a potential purchaser and the rights that the ID can offer.

This takes us of course to the external market and begs the question of the extent to which IDs will be prepared to enter into the s. 81 transfer market as sellers. Given the dominant role of a small number of IDs in the South Saskatchewan Basin, any reluctance on their part to participate will impair the development of a thick market in water rights in southern Alberta. Certainly, s. 11 of the IDA makes it more difficult for IDs to enter into the market as sellers, but it is not clear that this will make it (politically) impossible to do so and indeed the evidence that we have to this point is inconclusive. On the one hand, we have at least two examples of a single ID (the United Irrigation District) that was prepared to sell a portion of its water rights to other users to afford them greater security of supply. But, on the other hand, we have at least one other district (the SMRID) that has taken steps to afford itself a greater degree of autonomy by obtaining an amendment to its authorized purposes. In doing so it has chosen to emphasize internal trading as an option rather than selling a portion of its licensed allocation to existing non-irrigation users under s. 81 of the Water Act.

My own hunch is that the IDs will prove to be reluctant to enter the market as s. 81 transferees and that instead we will see IDs following a couple of alternative strategies. One strategy will be to push the margins of the agreements that they are authorized to enter into under the $I D A$. And, in a second strategy, one might expect to see the IDs lobbying the provincial government to further amend the $I D A$ to allow IDs to loosen the strings on the forms of agreements that they are permitted to enter into with third parties for non-irrigation purposes.

Assuming that the legislation is successful in fostering trade in water rights in Alberta, either internally within an ID or externally through $\mathrm{s} .81$ transfers and $\mathrm{s.} 33$ assignments, are the regulatory regimes adequate? More specifically, are the regulatory regimes robust enough to protect environmental, social, and community values that may be affected by the forms 
of transfer that these two statutes envisage? I have two concluding observations on this question. First, the only form of water rights transfer that is subject to serious public interest regulatory oversight is the s. 81 transfer under the Water Act. While the ID itself may supervise the reallocation of water within the ID, that supervision is directed at protecting the interests of the ID rather than a broader public interest. Similarly, s. 33 of the Water Act allows for some after-the-fact regulatory supervision, but there is no opportunity for preassessment of the effects of transfers.

The justification for exempting each of these two categories of transactions from any form of prior regulatory approval must be based upon the assumption that such arrangements can have no serious adverse effects for third parties or for the aquatic environment. For example, in the case of $\mathrm{s} .33$ arrangements, the argument might be that there can be no serious adverse effects on the basis that such arrangements are temporary. In the case of reallocations within an ID, perhaps the assumption is that such reallocations will have no effect outside the ID. While both may be true in some such transactions, it seems naïve to believe that all such transactions, and indeed the cumulative effect of a series of such transactions, will always be benign. This suggests that it may be important to develop some mechanism for protecting the public interest and third parties. Al a minimum. it seems reasonable to require parties to s. 33 agreements to provide notice of the content of those agreements to the Director and IDs and to provide annual summaries to the Director.

Second, while ss. $81-83$ of the Water $A c t$ do provide a procedure for assessing the impact of proposed transfers, it is not clear that it is sufficiently rigorous to fully protect third-party interests and environmental values. For example, the guidelines that the Department has developed might be amended to deal more clearly with the questions of the burden and standard of proof in relation to the "no impairnent, no adverse effect" test and night more clearly address the role of licensed quantities versus volumes actually consumed in reaching an assessment of no impairment or no adverse effect. Furthermore, the transfer scheme might be made to better serve environmental values if it were possible for private transferees to devote licensed flows to meeting water conservation objectives. Such a move would require an amendment to $\mathrm{s}$. 51 (2)(c) of the Water $\mathrm{Act}$, which currently provides that only government may hold a licence for "providing or maintaining a rate of flow of water or water level requirements."

\section{D. (NOT) Trusting The Market}

The Waler Act contains two different mechanisms for reallocating water rights, but the limited experience to date suggests that the policy or allocation principles underlying the two mechanisms may be quite different. On the one hand, it seems clear that market ideas underlie the s. 81 transfer mechanism. Thus, $\mathrm{s} .81$ is designed to facilitate the transfer, over time, of existing water rights from low value uses to higher value uses. Low value users will be compensated for giving up their right to use licensed volumes of high priority water. On the other hand, the single high profile example of a s. 33 agreement that we have (the southern tributaries agreement of 2001$)^{21 "}$ suggests that the $\mathrm{s.} 33$ assignment procedure is 
animated by an ethic of sharing and cooperation. ${ }^{230}$ That agreement resulted in the parties agreeing to proration a scarce resource rather than engage in a market-based reallocation emphasizing value to the user and willingness to pay. Government officials seem to have played a key role in brokering this agreement.

There are several possible explanations for this response. It could be an example of not trusting the market. That is to say, at a time of crisis, the key players were reluctant to trust not only the market but the entire statutory scheme based on the priority of licensees. But it could also be that the market was not yet responsive enough to provide a solution to the crisis. From this perspective, the s. 33 assignment procedure provided an important safety valve to the rigours of the system precisely because it can be put in place quickly by the players themselves and without the need for a governmental approval scheme. Transfers could not respond within the necessary time frame because the procedure for approving transfers is lengthy and complicated.

Perhaps the more important question pertains to the long term response to this sort of crisis. Will the combination of s. 33 assignments and s. 81 transfers lead junior licensees to enter the market and improve their priority through a s. 81 transfer? Or will we see junior licensees simply hoping that the precedent has now been set and that in water short years they can rely on senior licensees agreeing "to share the shortage" through the mechanism of a s. 33 assignment? If they choose the latter, they will weaken efforts to create a robust market in water rights in Alberta. For some this may represent an unusual example of the victory of an ethic of sharing over a more competitive market-based ethic. But if it be a victory it will not be without its risks. For example, what will happen if senior licensees tire of sharing and want to insist upon their priority? What if some licensees are included in the sharing but not others? In short, a junior licensee who wants real priority to justify a new investment will not be able to rely upon the possibility of a s. 33 agreement but will need to acquire a s. 81 transfer.

2:0 It bears emphasizing that there is nothing in the statutury language of s. 33 that requires that a s. 33 agreement should be informed by the ethic of cooperation rather than a market ethic and there is nothing that requires that a $\mathrm{s} .33$ agreement take the form of a prorationing agreement. Clearly we need to know more about the actual practice in relation to s. 33 agreements but the absence of even a statutory duty (c) inform the Director of such agreements makes this difficult. 